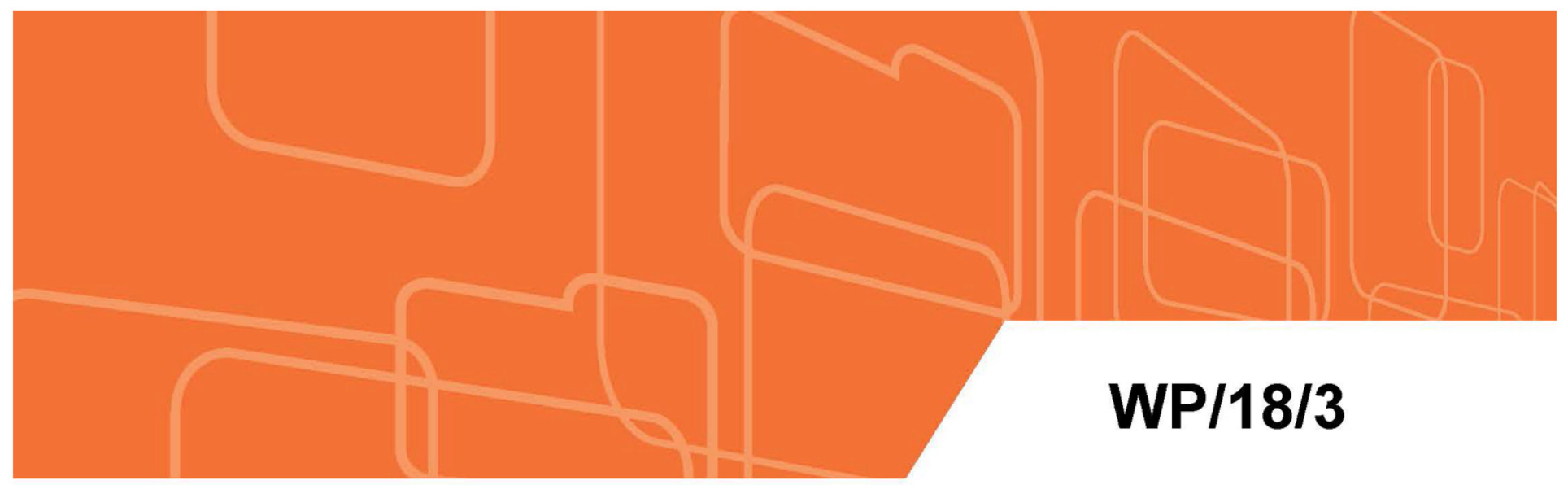

IMF Working Paper

\title{
Foreign banks and credit dynamics in CESEE
}

by Maria Arakelyan

IMF Working Papers describe research in progress by the author(s) and are published to elicit comments and to encourage debate. The views expressed in IMF Working Papers are those of the author(s) and do not necessarily represent the views of the IMF, its Executive Board, or IMF management. 


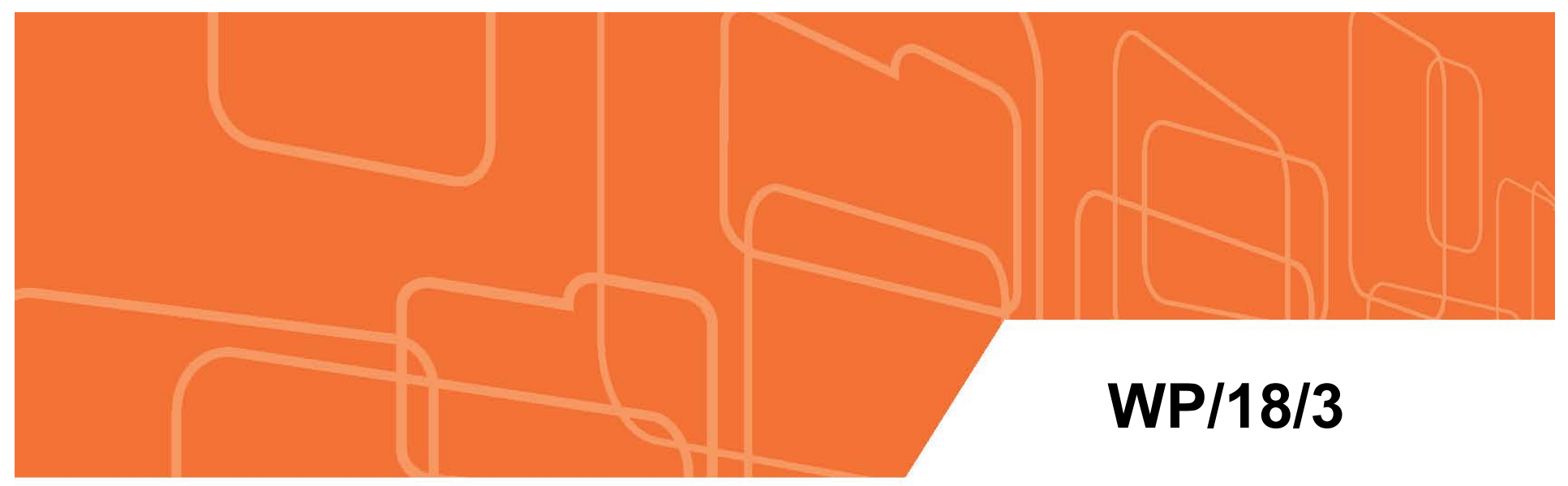

\section{IMF Working Paper}

\section{Foreign banks and credit dynamics in CESEE}

by Maria Arakelyan

IMF Working Papers describe research in progress by the author(s) and are published to elicit comments and to encourage debate. The views expressed in IMF Working Papers are those of the author(s) and do not necessarily represent the views of the IMF, its Executive Board, or IMF management. 


\title{
IMF Working Paper
}

Institute for Capacity Development

\section{Foreign Banks and Credit Dynamics in CESEE Prepared by Maria Arakelyan}

Authorized for distribution by Thomas Richardson

January 2018

\section{IMF Working Papers describe research in progress by the author(s) and are published to elicit comments and to encourage debate. The views expressed in IMF Working Papers are those of the author(s) and do not necessarily represent the views of the IMF, its Executive Board, or IMF management.}

\begin{abstract}
We use bank-level data on 16 CESEE economies over 2005-2014 to assess the role of foreign banks in the region's credit dynamics. We confirm that macroeconomic fundamentals of both host and home countries matter, as do the bank and parent bank characteristics. Moreover, we take a new approach by studying the drivers of differential credit growth between parent banks and their foreign subsidiaries. Host country macroeconomic fundamentals cease to play a significant role, while bank-level characteristics and in particular parent bank-level characteristics remain important. From policymakers' perspective, the paper provides further empirical evidence on the importance of monitoring the health of foreign parent banks as well as the potential regulatory changes in their home jurisdictions.

JEL Classification Numbers: G21, G15, F23, F65

Keywords: credit growth, foreign banks, emerging europe

Author's E-Mail Address: marakelyan@jvi.org

The paper was written with the guidance of Ben Kelmanson and Pragyan Deb. The paper has benefitted from comments and suggestions by Ralph de Haas, Maria Soledad Martinez Peria, Martin Petri, Dilyana Dimova, Scott Alasdair, seminar participants at the International Monetary Fund and Joint Vienna Institute.
\end{abstract}


Contents

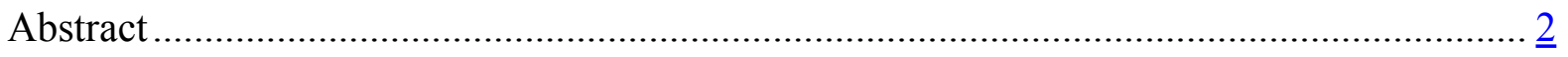

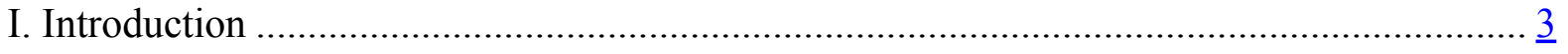

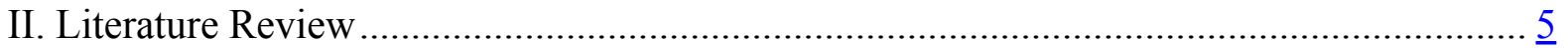

III. Data and Stylized Facts..........................................................................................

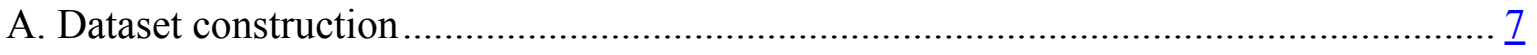

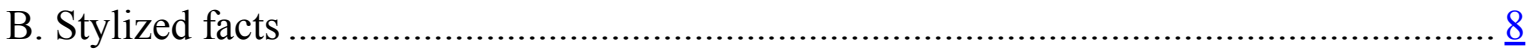

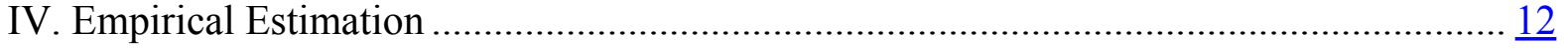

A. Empirical evidence on drivers of real credit growth ................................................ 12

B. Empirical evidence on drivers of differential credit growth ......................................... 20

C. Robustness checks........................................................................................... 24

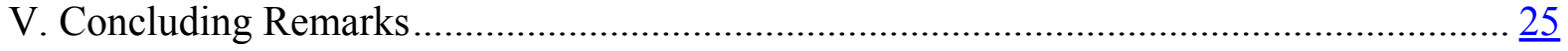

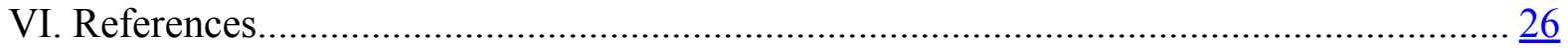

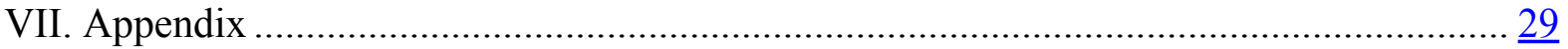

Figures

Figure 1: Foreign banks play a major role in CESEE and beyond ................................... $\underline{3}$

Figure 2: Post-crisis changes in real credit growth dynamics........................................ $\underline{9}$

Figure 3: Differential credit growth narrowed following the global financial crisis............... $\underline{9}$

Figure 4: Foreign banks diversify lending across CESEE countries ................................ 10

Figure 5: Real credit growth vs. growth dynamics and bank-level characteristics ............... 11

Figure 6: Drivers of credit growth: Table 1, regressions (1) and (2) ................................. $\frac{17}{17}$

Figure 7: Drivers of credit growth: Table 2, regressions (1) and (2) ................................ $\frac{19}{(2)}$

Figure 8: Drivers of differential credit growth vs. foreign bank credit, Table 3, regressions (2)

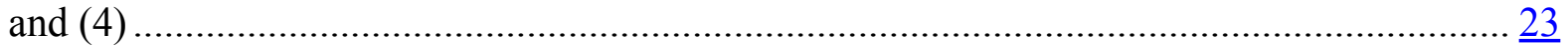

Tables

Table 1: Drivers of credit growth.................................................................................. 16

Table 2: Drivers of credit growth: domestic vs. foreign ............................................... 18

Table 3: Drivers of foreign bank credit and differential credit growth............................. 22

Table A 1: Data sources ...................................................................................... 29

Table A 2: Descriptive statistics .............................................................................. 29

Table A 3: Alternative model specifications …......................................................... $\underline{30}$

Table A 4: Alternative estimation method (GMM) ................................................... $\underline{31}$ 


\section{INTRODUCTION}

In the two decades preceding the great recession, the global economy witnessed a massive expansion in banks' international activities, both in the form of larger cross-border credit flows as well as an expansion of foreign subsidiary and branch networks. Central, Eastern and Southeastern European (CESEE) ${ }^{1}$ countries fully embraced the trend of increased financial integration. Foreign, predominantly Western European, banks rapidly increased their presence in CESEE starting in the mid-90s as governments were looking to privatize their banking sectors, increase efficiency, boost competition and benefit from knowledge transfer. This resulted in an increasing share of foreign banks in the number of total banks in the CESEE region from just $27 \%$ in 1995 to a pre-crisis peak of $70 \%$ in $2008,{ }^{2}$ ahead of its regional peers (see left panel in Figure 1). Foreign banks also became dominant across CESEE region in terms of credit provision (as well as banking sector assets), comprising on average around $80 \%$ of total credit, and even higher at close to $100 \%$ in some countries such as Estonia and the Czech Republic (see right panel in Figure 1).

\section{Figure 1: Foreign banks play a major role in CESEE and beyond}
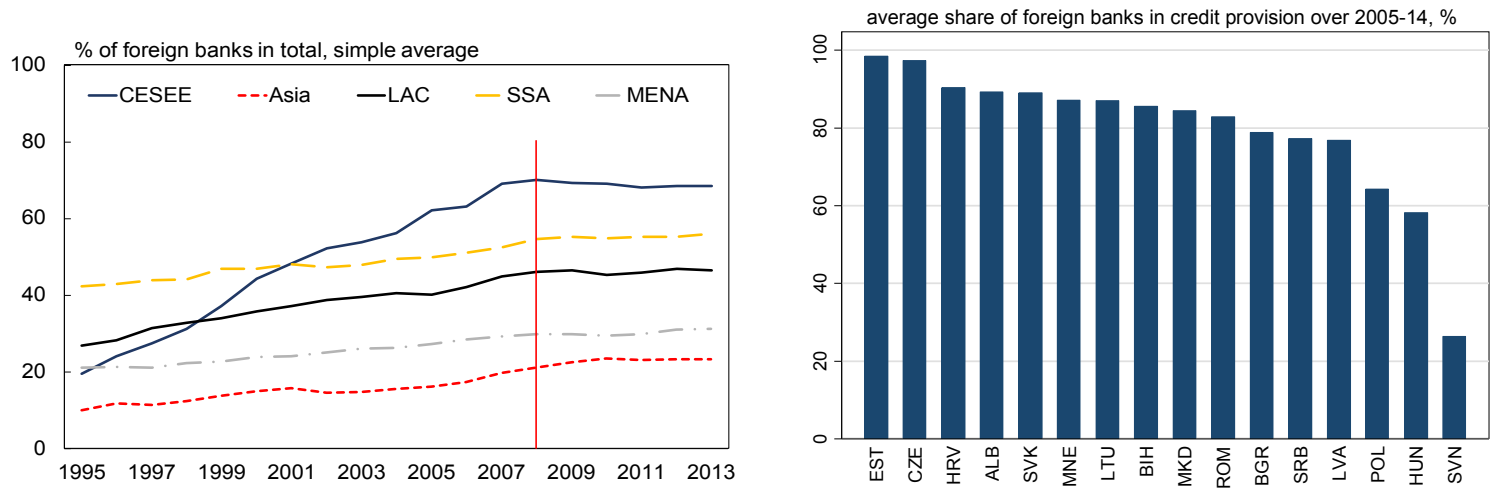

Sources: Bank Ownership Database compiled by Stijn Claessens and Neeltje van Horen $(2009,2013)$, Bankscope and Fitch Connect

The prevalence of foreign banks in the CESEE region along with a credit boom prior to the crisis thus made the countries potentially more vulnerable to credit supply shocks following the global financial crisis (GFC). ${ }^{3}$ Credit recovery in CESEE following the crisis has been sluggish and heterogeneous across the region, despite the fact that it is largely dominated by

\footnotetext{
${ }^{1}$ In this paper the countries captured by the abbreviation are Albania, Bulgaria, Bosnia and Herzegovina, Croatia, Czech Republic, Estonia, Hungary, Latvia, Lithuania, Macedonia, Montenegro, Poland, Romania, Serbia, Slovakia and Slovenia.

${ }^{2}$ Based on Bank Ownership Database compiled by Claessens and van Horen 2014.

${ }^{3}$ With the advent of the GFC, these risks triggered a prompt response in the form of Vienna Initiative launched in early 2009, followed by Vienna 2.0 in 2012 aiming to safeguard financial stability in Emerging Europe and prevent uncoordinated exits of foreign banks (see de Haas et al. 2015).
} 
only a handful of the same foreign banks. In the meantime, banks remain the key source of financing for CESEE economies, as financial markets in the region are largely bank-based. ${ }^{4}$

The focus of the empirical literature prior to the crisis was tilted towards the benefits of increased foreign bank presence. The analysis has since broadened to incorporate the risks foreign banks might pose for credit provision of their host economies. Understanding the underlying transmission mechanisms of shocks and potential use of internal capital markets have become increasingly more important (see e.g. de Haas et al. 2010, Cetorelli and Goldberg 2012).

Against this background, our study focuses on the following questions. First, we identify bank-level drivers of credit growth and investigate how foreign banks differ from domestic ones. While this question is not new and there has been a major body of new evidence on the topic following the crisis, we provide new empirical evidence for the region by extending our dataset beyond the immediate aftermath of the global financial crisis. With data until 2014 we include part of the gradual recovery after the height of the euro area crisis, which had severely impacted many euro area banks. Second, we try to explore why foreign parents behave differently - in terms of expanding their credit portfolio - in their home country vs. their host countries. Taking a new perspective, we address this question by studying the differences in the bank-level credit growth in foreign banks' home countries and in the countries where the banks run subsidiaries. In some ways, this can be thought of as a proxy measure for the banks' internal capital market activity and, in effect, controls for some of the unobserved bank characteristics, such as the group's strategic and risk appetite. Studying this differential credit growth can help to shed some light on the factors driving banks' decision on the allocation of resources between their home market and overseas subsidiaries. Such an approach could offer insights to governments and regulators on the potential channels for shock transmission from parent banks and suggest policy action to facilitate unhindered credit supply from foreign banks.

We find that foreign banks with stronger balance sheet characteristics are able to grow their credit portfolios faster. These characteristics include healthy assets, better capitalization, safer funding structure and higher profitability. Economic performance is also positively related to credit growth, implying that parent banks may be looking to allocate their (scarce) resources to subsidiaries in faster growing economies. Overall, parent characteristics also play a significant role in driving both credit growth and in particular, the differential credit growth. From policymakers' perspective, this could imply that regulatory changes in the parent banks' home markets that affect these characteristics could spill over to the host country credit dynamics.

The rest of the paper is organized as follows: section II provides a brief overview of the literature in the area of foreign bank ownership and its role in credit provision. Section III describes our dataset and provides some stylized facts. Section IV lays out our empirical methodology and main results. Finally, section V provides some conclusions and policy implications.

\footnotetext{
${ }^{4}$ See Arakelyan and Mühlberger 2015.
} 


\section{LiterATURE REVIEW}

Although the empirical literature on foreign banks and their role in credit provision is extensive, the global financial crisis has brought the issue back into the spotlight. Prior to the crisis, the literature tried to understand the reasons for the dominant presence of foreign banks, ${ }^{5}$ while more recently it has sought to document the implications of foreign banks' presence.

Foreign banks dominate Central, Eastern and Southeastern European financial markets. From the hosts' perspective, the post-communist countries in the region were keen on attracting foreign capital, developing and privatizing their state-dominated banking sectors as they were transitioning to market economies. From the foreign banks' perspective, there were a number of attractive regional characteristics. These included positive economic growth prospects, existing relationships with clients that had invested in these countries (i.e. correlation of foreign bank presence with trade and FDI flows), absence of entry barriers, low physical distance to the markets and a similar culture and institutions. A more comprehensive literature review can be found in Clarke et al. 2001; Claessens and van Horen 2013; Claessens and van Horen 2008; Focarelli and Pozzolo 2005.

As regards the literature on the consequences of foreign bank presence, it is often divided into three areas: (i) the impact of foreign banks on competition and efficiency; (ii) the impact of foreign banks on access to finance; and (iii) more recently, understanding the role of foreign banks on lending, financial stability and transmission channels of shocks, for instance via internal capital markets. Despite a vast body of literature on all of these questions, the evidence is not always conclusive, often varying depending on the region or time period. A detailed review of the literature in these areas is provided in Cull and Martinez Peria 2010; de Haas 2014.

Our paper can primarily be attributed to the last strand of literature, as we study the role of foreign banks in CESEE on lending growth over the recent decade. Controlling for time fixed effects (along with a host of other controls), we find that banks with stronger balance sheet characteristics are likely to expanded their credit portfolios more rapidly. We also shed some light on how and why parent banks differentiate lending in subsidiaries relative to their home markets.

On the first strand of literature, there seems to be a consensus that together with foreign banks comes foreign capital and know-how, helping to boost efficiency and putting pressure on domestic banks to increase their competitiveness (see Claessens et al. 2001; Bayraktar and Wang 2004).

In contrast, there is less of a consensus regarding the role of foreign banks in firms' access to finance, especially of small and medium-sized enterprises (see Cull and Martinez Peria 2010 for details). There is a concern that the foreign banks "cherry-pick" the best customers, leaving the domestic banks with a weaker customer base. At the same time, some crosscountry studies argue that domestic banks possess "soft" information about the clients which foreign banks often lack, leading to constrained lending to SMEs. Using a theoretical model and then testing it on a sample of low income countries, Detragiache et al. 2008 show that

\footnotetext{
${ }^{5}$ For a more detailed literature review please see de Haas 2014; Cull and Martinez Peria 2010.
} 
domestic banks are better than foreign banks at monitoring soft information. Brown et al. 2012 find that the majority of small and opaque firms in Eastern Europe are discouraged from applying for loans. However, they do not find evidence that foreign bank presence results in stricter loan approval decisions. In contrast, studying Eastern European firms, Giannetti and Ongena 2012 conclude that firms have the same access to credit irrespective of whether they borrow from a domestic or a foreign bank.

Finally, with regards to the role of foreign banks in banking sector stability and lending, the evidence can be tentatively divided into two strands of work: before and after the crisis. The first strand finds evidence of a stabilizing role of foreign banks as they are a source of diversification and act as a shock absorbent in times of local crises (see de Haas and van Lelyveld 2006; Arena et al. 2007). The post-crisis literature, focuses on the role of foreign banks in shock transmission, particularly in times of crisis. There is a substantial body of work that finds supporting evidence for the view that foreign banks can act as a source of contagion, increase volatility and import economic or financial shocks from home countries of foreign banks to their host countries (e.g. Cull and Martinez Peria 2013).

Focusing on European banks, Barba Navaretti et al. 2010 find that, supported by internal capital markets, retail and corporate lending of foreign affiliates has been stable or increasing even over 2007-2009. In contrast, Cetorelli and Goldberg 2010 analyze the differences in funding sources for domestic and foreign banks, showing that this could lead to their varying sensitivity to external shocks. In addition to deposits, other sources and cross-border borrowing which are the main funding sources for domestic banks, foreign bank subsidiaries also have access to the internal capital market of their parent banks. This can act both as a source of strength and of weakness, depending on the nature of the shock that has hit the subsidiary and its parent bank. As both domestic and foreign banks are subject to external shocks via cross-border funding and/or internal capital market, it is thus difficult to determine a priori which banks would ensure more stable domestic lending (Cull et al. 2017). Tracking intra-group support measures directly is not an easy task as they can take a variety of forms and differ across institutions (BIS 2012). Using confidential regulatory data on all U.S. banks with foreign subsidiaries and branches, Cetorelli and Goldberg 2012 show that funds are not reallocated to the same degree across the network of foreign entities as a response to funding shocks to the parent.

There has also been increased attention to a more granular approach that tries to disentangle the impact of (parent) bank and macroeconomic characteristics on lending and assess their role in shock transmission. For instance, de Haas and van Lelyveld 2014 use data on the 48 largest multinational banking groups and find that their credit growth slowed about twice as much relative to domestic banks over the GFC, thus acting as a source of instability. Moreover, the vulnerability of subsidiaries increased, due to larger reliance of the parent bank group on wholesale funding. Using bank-level data, Choi et al. 2013 find robust evidence that foreign banks curtailed credit growth more relative to other banks during the global financial crisis. They also find some empirical evidence that funding structure and parent bank capitalization help to explain lending patterns of foreign banks during the recent crisis.

Our results also provide supportive evidence for the importance of the parent bank characteristics on real credit growth in the subsidiaries, with stronger parents being able to better grow their portfolios in the host economies. Using macro level data in their cross- 
country study, Feyen et al. 2014 conclude that private credit growth is highly sensitive to cross-border funding shocks, especially in the CEE countries. While the authors do not find evidence that high foreign ownership per se is a problem, their findings suggest that differences in the funding structures are critical. Countries with a riskier funding structure (higher loan-to-deposit ratios) and a high reliance on foreign funding relative to local deposits appear to be more vulnerable. Chen and $\mathrm{Wu} 2014$ also find empirical evidence that banks in countries with stronger banking regulation had higher credit growth during the crisis. Looking from individual firms' perspective, Ongena et al. 2015 find that internationally-borrowing domestic and foreign-owned banks contracted their credit more during the crisis than domestic banks that are funded only locally.

Our contribution to the literature is twofold. First, we provide some new empirical evidence on implications of foreign bank presence on credit growth in the CESEE over the recent decade. Second, we take a new approach in studying differences in real credit growth performance between parent banks and their foreign subsidiaries.

\section{Data And STylized Facts}

\section{A. Dataset construction}

Our analysis is based on annual bank-level data in 16 Central, Eastern and Southeastern European (CESEE) countries spanning a decade from 2005 to 2014. Our dataset covers over 200 domestic banks and foreign-owned bank subsidiaries, both currently active and those that have been active during this period but are now out of business. Foreign bank branches ${ }^{6}$ are not included in our analysis due to lack of data, as they, in contrast to subsidiaries, are not separate legal independent entities that need to fulfill the regulatory and disclosure requirements of host countries (see IMF 2015). In any case, foreign bank branches only play a minor role in CESEE (IMF 2013).

We obtain balance sheet information for all banks in CESEE from the Bankscope database. Specifically, we obtain data on credit growth, ${ }^{7}$ asset quality, funding, capitalization, profitability and liquidity. The balance sheet data is at a consolidated level when available. Our dataset includes commercial, cooperative, investment and savings banks as well as micro-financing institutions.

Given the question of our analysis, information about the ownership of the banks operating in CESEE is essential. Bankscope provides information about global ultimate owners of banks, which allows us to eliminate intermediate ownership and trace the ultimate parent of the foreign subsidiary. However, Bankscope retains information on global ultimate owner of the banks only for the most recent period. In order to trace back the historical ownership of banks included in our analysis, we use Bankscope's annual historical data vintages going back to 2005, tracking name and identifier changes between the different data vintages in order to avoid double counting. The bank ownership information is further complemented by

\footnotetext{
${ }^{6}$ See Cerutti et al. 2007 for factors influencing international banks' decision on organizational form.

${ }^{7}$ Credit growth data is based on nominal credit in the local currency (see e.g. Arena et al. 2007). We use CPI to get real credit growth.
} 
information obtained from individual bank websites and annual reports. Based on this information, we construct a foreign ownership dummy variable that is equal to 0 when the bank is domestically owned and to 1 when it is foreign owned (based on a $50 \%$ benchmark for foreign ownership). Our micro-level data suggests a pre-crisis peak in foreign ownership both in terms of total banking sector assets and credit provision in the CESEE region.

Having identified the parent of the foreign banks operating in the CESEE region, we obtain historical balance sheet data for the parent banks from Bankscope and supplement it using Fitch Connect. The parent bank balance sheet data is on an unconsolidated basis, for the entity operating in the home country of the banking group. When such unconsolidated data is not available, we use consolidated data.

Finally, we supplement the bank-level data with macroeconomic characteristics of both host countries and the parent banks' home countries. Table A1 in the appendix provides the detailed sources of the obtained variables.

In order to eliminate outliers driving the overall results, we perform a range of steps. The tails of credit growth observations (above $100 \%$ or below $-100 \%$ ) are dropped, as these are likely to be a result of newly established subsidiaries or mergers and acquisitions that distort the results of the empirical analysis. This is similar to the approach followed in the literature (see IMF 2015; de Haas and van Lelyveld 2006; Choi et al. 2013; Chen and Wu 2014). We perform a similar procedure for the credit growth of parent banks. In addition, we drop banks that have credit growth observations for less than 4 years. Further, the data is winsorized at 1 percent level.

\section{B. Stylized facts}

There was a significant decline in credit growth in the post-crisis period in CESEE, for both domestic and foreign owned banks, with considerable cross-country heterogeneity. While real credit growth averaged over 20 percent during the pre-crisis boom (prior to 2008), it fell below 5 percent after the crisis (see Table A2). These aggregate figures, however, conceal substantial cross-country heterogeneity. Following the crisis, real credit growth on average remained negative over 2009-14 in the Baltics, Hungary, Slovenia and Romania according to our dataset (see left panel in Figure 2), while credit in Poland and most of Southeastern Europe, continued to expand, even though at a slower pace. This is largely in line with macro-level data.

Although foreign banks remain dominant across the CESEE region in terms of the overall stock of credit, for a sustained period they lost their lead to domestic banks in terms of credit growth dynamics following the GFC (see right panel in Figure 2). On average, real credit growth in foreign banks was stronger than domestic credit only in some of the countries, such as Slovenia and Czech Republic, after the crisis.

Apart from different macroeconomic dynamics, one possible explanation for divergent credit trends within CESEE could be differences in parent bank characteristics that dominated the local markets. In order to shed some light on the role played by foreign parent banks, we also look at the differences between the real credit growth rate of foreign subsidiaries and the corresponding parent banks' credit growth in their home markets. The idea is to capture 
Figure 2: Post-crisis changes in real credit growth dynamics
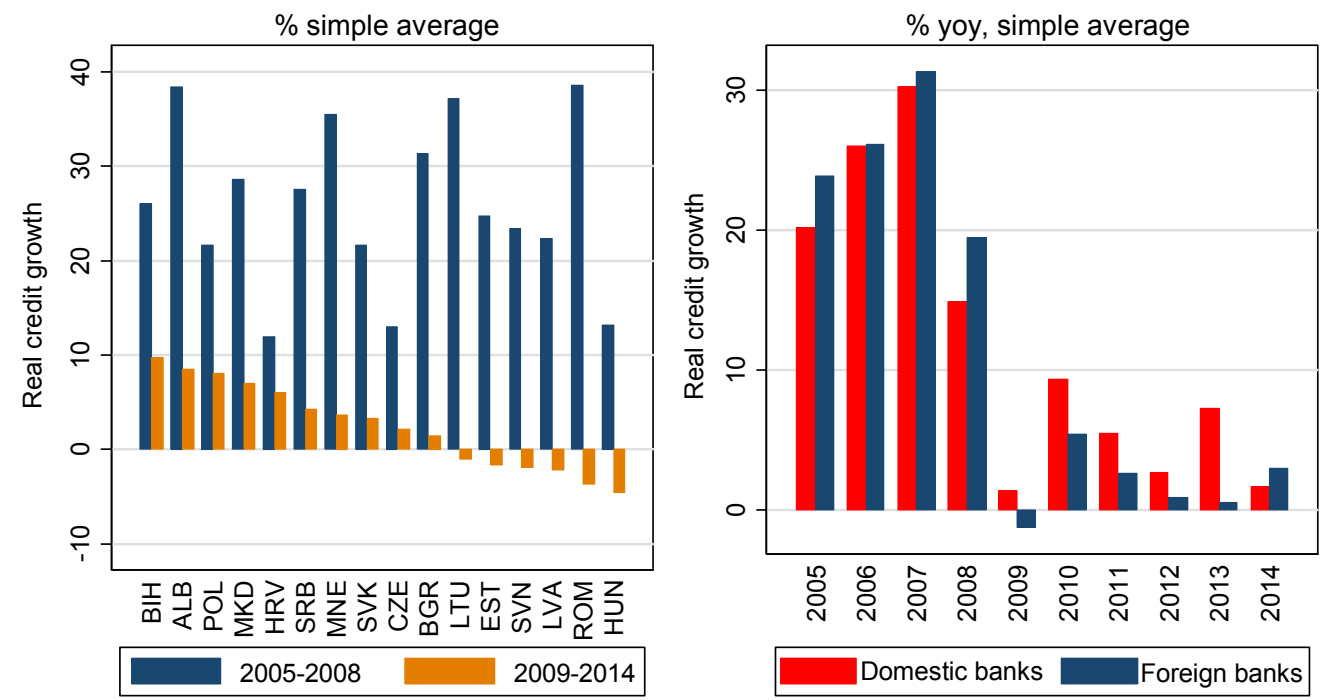

Sources: Bankscope, Fitch Connect

differential behavior within the same banking group, which could also capture internal capital market activity. We term this differential behavior - "differential credit growth".

Positive differential credit growth implies that real credit growth in the host country exceeds real credit growth in the home market of the bank, while negative differential credit growth, respectively, shows the opposite.

Differential credit growth appears to be largely positive, but there is substantial variation

Figure 3: Differential credit growth narrowed following the global financial crisis

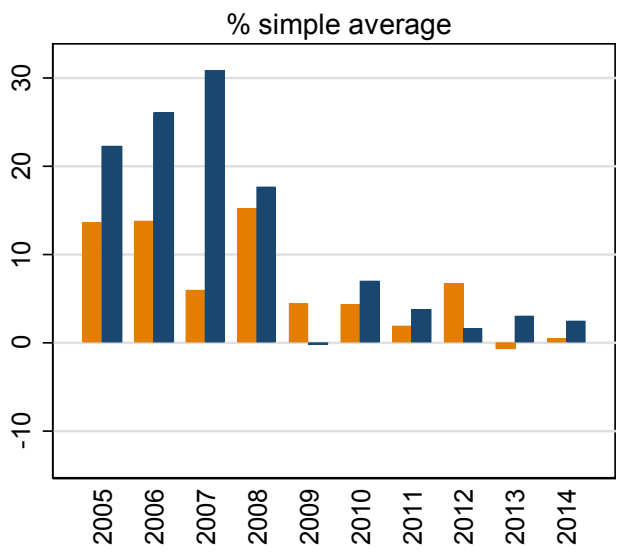

Differential credit growth Real credit growth, foreign

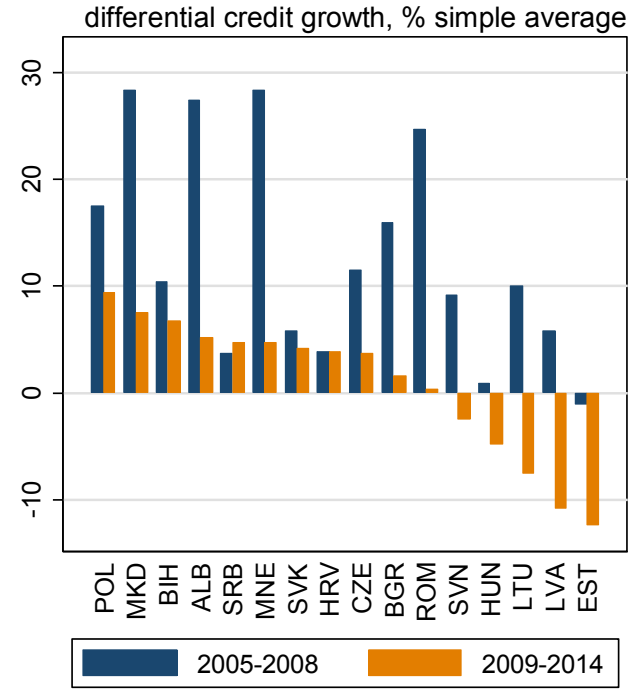

Sources: Bankscope, Fitch Connect 
over time and across countries. Differential credit growth was positive throughout most of the last decade, as one would expect, given that the host economies are emerging countries with deepening financial markets, while the parent banks' home economies are slower growing saturated advanced economies (see Figure 3). However, on average, the difference reversed sign in 2013, when stronger real credit growth was observed in the home markets against moderate (or negative) credit growth by foreign subsidiaries in their host markets due to deleveraging. Prior to 2009 , on average, real credit grew by over $10 \mathrm{pp}$ faster in subsidiaries compared to banks' parent countries, while this gap declined to below 5pp over 2009-14. Again, as in the case with real credit growth, average numbers disguise significant differences across countries and parent banks (right panel of Figure 3). Foreign subsidiaries in the Baltics in post-crisis times seem to have fared worst, on average posting lower credit compared to parent banks' credit growth in their home markets.

There is also evidence of significant heterogeneity among subsidiaries of the same parent in different countries. Figure 4 illustrates the distribution of differential credit growth between 2005 and 2014 over parent banks covered in our analysis. Two things can be inferred from this chart. First, banks differentiated credit expansion strategies across their subsidiaries. Second, different banks did this to a different extent as suggested by the size of the whiskers on the plot.

Figure 4: Foreign banks diversify lending across CESEE countries

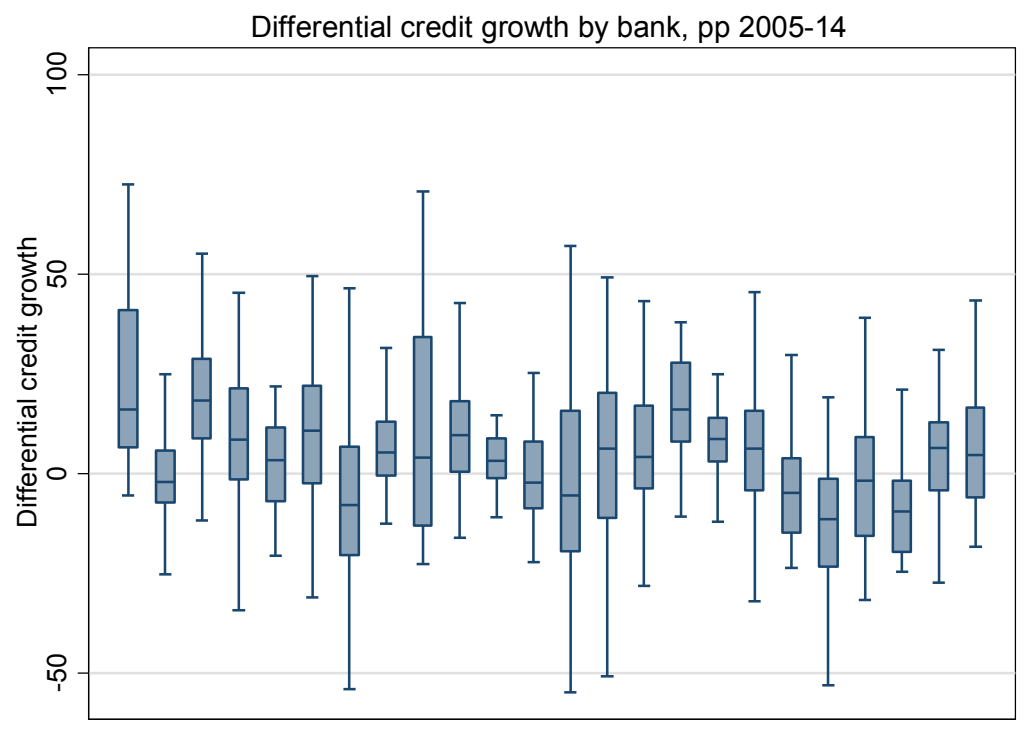

Sources: Bankscope, Fitch Connect

A question arises - why do CESEE countries with a substantial overlap of parent banks exhibit such large differences in credit dynamics? One possible explanation could be differences in macroeconomic conditions and bank characteristics operating in these markets. While a more rigorous econometric analysis of this question is conducted in the next section, here we look at basic correlations between credit dynamics and some of the key macroeconomic and bank-level variables that have been found to be important in the empirical literature. 
The charts below (Figure 5) plot our real credit growth measure against some of the potential explanatory variables. The lines correspond to correlation between credit growth variable and explanatory variable, red for domestic and blue for foreign.

Figure 5: Real credit growth vs. growth dynamics and bank-level characteristics
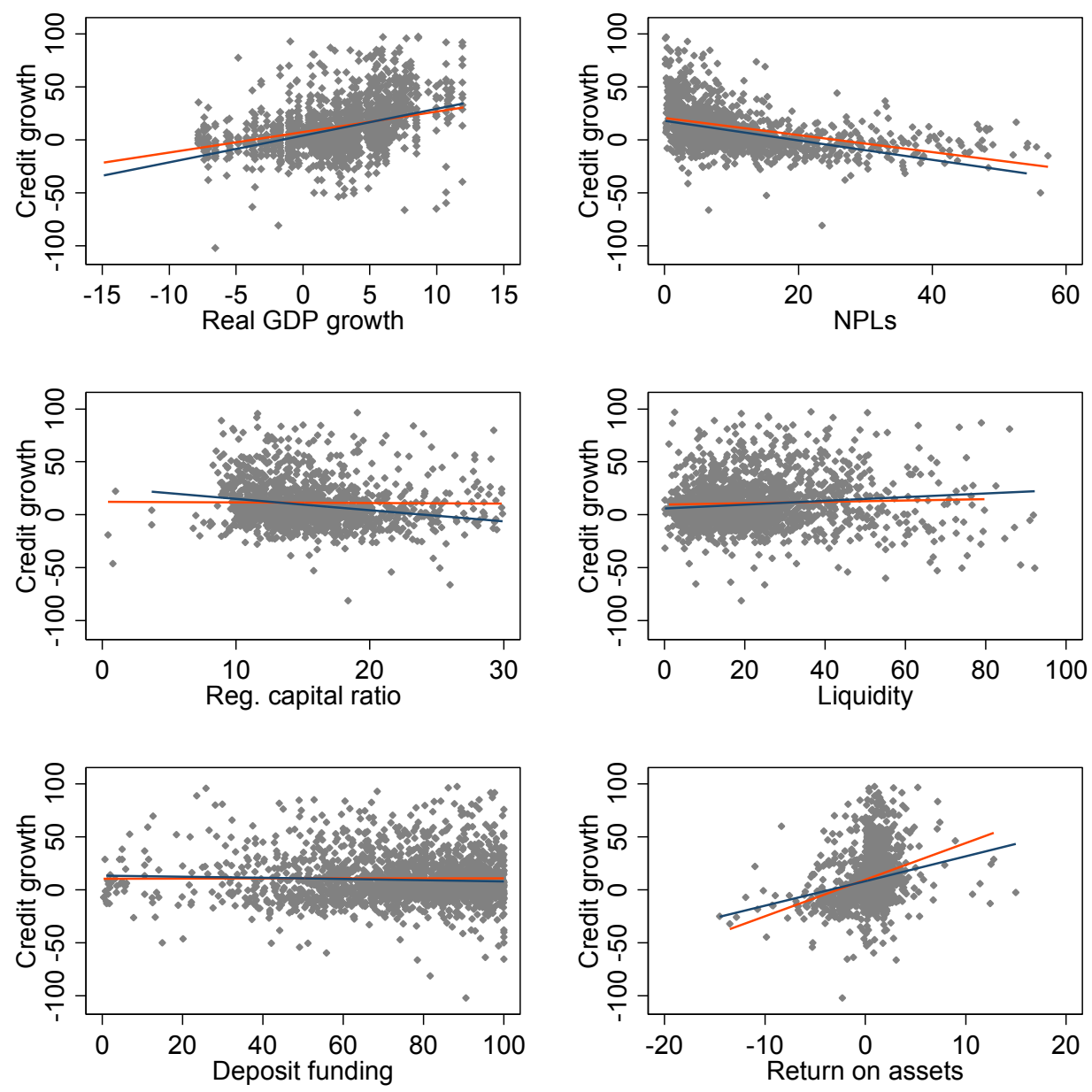

— Fitted values, domestic — Fitted values, foreign

Sources: Bankscope, Fitch Connect

First, focusing on macroeconomic fundamentals:

- Real GDP growth shows positive correlation with credit growth.

- Foreign banks appear to behave more pro-cyclically compared to domestic ones.

Our statistical analysis also illustrates the correlations between credit growth and bank-level characteristics.

- Higher levels of distressed assets are associated with lower credit growth. This is intuitive as non-performing loans are likely to weigh on banks' credit expansion. 
- There is a negative relationship between capitalization levels of the foreign banks and their credit growth dynamics. Better-capitalized banks are likely to be in a position to expand their credit portfolio. At the same time, higher capitalization may be a sign of a more risk averse stance of the bank or a result of regulatory pressure, leading to a more conservative business model and lower lending growth. Consequently, the sign of the relationship is not trivial.

- In contrast, more liquid banks seem to have higher credit growth both for domestic and foreign banks. Similar to capitalization, the sign of the relationship between the two is a priori not obvious.

- Higher profitability levels are also associated with faster credit expansion, especially in the case of domestic banks.

- The relationship is less obvious between the funding structure of the banks (proxied by deposits over total funding ratio) and real credit growth.

Summary statistics of the data can also be found in the Table A2 in the Appendix. In the next section, we further analyze which of these relationships holds when controlling for other relevant characteristics and compare it with other findings in the related literature.

\section{EMPIRICAL ESTIMATION}

We assess the drivers of bank-level credit growth and differential credit growth in two steps. First, we explore the macroeconomic and bank-level drivers of credit growth, treating foreign bank subsidiaries as standalone entities. The focus is to illustrate the differences between lending behavior of foreign banks and their domestic counterparts (subsection A). Second, we study the drivers of differential credit growth between foreign subsidiaries in their host countries and corresponding parent banks in their home markets (subsection B). To conclude, we present some alternative model specifications and estimation methods as robustness checks to our baseline regressions.

\section{A. Empirical evidence on drivers of real credit growth}

\section{Empirical framework}

We use panel regressions with bank fixed effects ${ }^{8}$ as indicated by Hausman tests. In addition to controlling for unobserved bank-level characteristics, we also include time fixed effects to capture the overall macroeconomic cycle. The dependent variable in the equation (1) presented below is the real annual credit growth of banks included in the analysis. We opt for credit in real terms in order to capture inflation differentials across countries.

$$
\text { Creditgr }_{i j t}=\alpha+\beta_{1} F_{B O} O_{i j t}+\beta_{2} \text { Macro }_{j t}+\beta_{3} \text { Bank }_{i j t-1}+\beta_{4} \text { Inter }_{i j t}+\mathrm{y}_{t}+\eta_{i}+\varepsilon_{i j t}
$$

\footnotetext{
${ }^{8}$ Similar to Cull and Martinez Peria 2013; Choi et al. 2013
} 
where

Creditgr $_{i j t}$ is the real annual growth of gross loans of bank $i$ in country $j$ and year $t$ $\alpha$ is the intercept and $\beta$ s are the coefficients (or coefficient vectors) of interest $F B O_{i j t}$ is a time varying dummy that equals 1 when the bank is foreign owned or 0 otherwise

Macro $_{j t}$ is the matrix of macroeconomic variables of the host country

Bank $_{i j t-1}$ is the matrix of bank balance sheet characteristics of bank $i$

Inter $_{i j t}$ includes interaction terms, that can capture potential nonlinearities

$\mathrm{y}_{t}$ captures the time fixed effects

$\eta_{i}$ captures bank fixed effects

$\varepsilon_{i j t}$ is the error term

Depending on the model specification, the exact choice of control variables differs. We use bank-level clustered, robust standard errors to correct for heteroscedasticity. The reported results are robust to clustering standard errors at the country and country-year levels. As is typical of reduced-form estimation models, there are risks of potential endogeneity issues. To alleviate these issues all bank-level characteristics enter the regressions with a lag (see e.g. Chen and $\mathrm{Wu} 2014$ ). To address endogeneity concerns, in the robustness section we also examined a dynamic system GMM that treats bank variables as endogenous and includes a lag of the dependent variable.

\section{Macroeconomic variables}

Host country macroeconomic characteristics are likely to play an important role in determining credit expansion. We include real GDP growth as a proxy for demand conditions. In the case of foreign banks, this variable also proxies for their business strategy - faster growing economies are likely to be a more attractive place for foreign banks to boost lending, thereby resulting in a more rapid expansion of their lending portfolio. Furthermore, we control for currency depreciation (against the USD) in our regressions. The CESEE countries have diverse exchange rate regimes (from floating, pegs to euro area membership) and experienced episodes of currency fluctuations over the analyzed time period. This could impact real credit growth through a number of channels. First, credit provided by the banks in our sample consists of loans both in domestic and foreign currencies (often the latter being dominant), thus currency movements can have a direct impact on the size of the credit portfolio of banks expressed in local currency. Second, an indirect impact can come through the inflation pass through channel, affecting inflation and thus real credit growth. Third, a weakening currency could positively affect credit growth to export-oriented firms which will find themselves more competitive. Fourth, depreciation would reduce earnings for parent banks as the latter are likely to value earnings in their domestic currency, possibly negatively affecting credit growth (see Bonin and Louie 2016). 


\section{Bank characteristics}

Bank-level characteristics can have a large impact on the ability and willingness of banks to expand their credit portfolio. In our baseline specification, we include indicators to capture asset quality, bank capitalization, funding structure, profitability and liquidity.

- Asset quality is controlled for by introducing the ratio of non-performing loans (NPLs) over total loans. Higher NPL levels are likely to constrain credit growth (see Stepanyan and Guo 2011; European Investment Bank 2014; Peek and Rosengren 2000; Balgova et al. 2016). However, we should note that part of this negative relationship could be driven by the construction of the variable, as gross loans appear in the denominator of the NPL ratios (even though we use a lagged variable). A limitation to using this indicator could be the potential inconsistencies across banks in reporting NPL figures (see Barisitz 2011).

- Capital adequacy, that shows the loss absorbing ability of the banks, is controlled for by including the total regulatory capital ratio. As mentioned in the previous section, it is hard to determine the sign of the relationship a priori.

- In order to account for the stability of the funding sources of the bank, we control for the ratio of customer deposits over total funding. A higher ratio implies a more stable funding profile; as other (wholesale) funding is more prone to sudden stops. Following the global financial crisis, CESEE banks started rebalancing their funding models, shifting away from wholesale funding or parent bank internal capital markets towards deposit funding (see e.g. IMF 2013). As indicated in the empirical literature overview section, more stable funding seems to have a positive impact on credit growth.

- To account for the liquidity profile of banks we include the ratio of liquid assets to total assets into our regressions. A priori, the direction of the relationship between bank liquidity and lending growth is not straightforward, and among other things, can depend on banks' willingness to take on risk as well as their funding structure. Our stylized facts suggest a weak positive relationship between the two.

- In line with other empirical literature on the subject, we also control for profitability of banks. We do so by including the banks' return on average assets (ROAA). A higher ROAA is likely to be associated with more dynamic credit growth, as also seen in our data sample.

Finally, we include information on the foreign ownership of banks. As mentioned in the previous section, our dummy variable is equal to 1 when a bank is foreign owned and to 0 otherwise. This allows us to distinguish between the lending behavior of foreign and domestically owned banks.

\section{Estimation results}

We begin by studying the drivers of real credit growth across both domestic and foreign banks in CESEE. In the first set of regressions we control for macro and bank-specific characteristics for all banks (see Table 1). In these specifications, foreign banks are treated as separate entities from their parents and parent characteristics are not taken into account. Columns (1) and (3) in Table 1 display the baseline regressions that contain NPL levels, while columns (2) and (4) contain only ROAA and not NPLs. The reason for this separation 
is that the two are strongly negatively correlated. The last two specifications in Table 1 also include the Foreign Dummy in separate specifications with NPLs and ROAA.

\section{Macroeconomic fundamentals of the host country, such as higher GDP growth, positively impact real credit growth, so does currency depreciation.}

- In-line with findings in the empirical literature, our results suggest a positive relationship between GDP growth and real credit growth, that is strongly significant (columns (1) -

(4) in Table 1). This implies that bank lending behaves pro-cyclically. GDP stands as a proxy for credit demand. Although, we acknowledge that this is not a perfect measure, it is commonly used in the empirical literature studying micro-level credit growth.

- As regards currency depreciation, our results suggest a positive, although often not statistically significant, relationship between depreciation and real credit growth. This finding is also in line with the empirical literature and implies that the impact of foreign currency valuation effects and/or demand effects as a result of an altered competitiveness of the exporting sectors likely dominate other (adverse) effects.

\section{Healthy credit portfolio and profitability support real credit growth.}

Turning to bank-level characteristics, our results suggest that balance sheet indicators such as healthy assets (measured by the share of NPLs in total loans) and high bank profitability play an important and highly significant role.

- As expected, high levels of NPLs hinder credit growth. This might explain the lack of credit growth in the CESEE after the global financial crisis, where NPLs have remained sticky. While the high level of NPLs was no doubt a legacy of the pre-crisis booms in many of these economies, they are also partially driven by weaknesses in the legal and regulatory frameworks, such as the inefficiency of insolvency frameworks, underdeveloped markets for distressed debt and weaknesses in banks' ability to assess borrower creditworthiness. As a robustness check, we also tried introducing the growth rate of NPLs instead of levels which left our overall results unaffected (these regressions are not reported).

- In line with the empirical literature, higher bank profitability rates, as captured by return on average assets, are also associated with higher real credit growth. As a robustness check we also used return on equity and net interest margin as alternative measures of bank profitability (results not reported due to space considerations). The results of these regressions support the laid-out hypothesis.

\section{Better capitalized banks are likely to support credit growth.}

Our baseline regression results suggest that better capitalized banks positively affect banklevel credit growth. Better capitalized banks are better able to absorb losses, hence sustaining lending (see Kapan and Minoiu 2013). Controlling for a number of relevant characteristics changes the negative relationship between capitalization and credit that was implied by the stylized facts of our dataset in the previous section.

\section{Safer funding structures are positively associated with credit growth.}

A higher share of customer deposits in total funding is associated with higher credit growth, despite the negative correlation observed in the stylized facts. This implies that banks with 
safer funding structures that are less reliant on unstable forms of funding were able to grow their credit portfolio more over the past decade in CESEE. This is also in line with other findings in the literature.

Table 1: Drivers of credit growth

\begin{tabular}{|c|c|c|c|c|c|}
\hline & & $\begin{array}{c}(1) \\
\text { All banks }\end{array}$ & $\begin{array}{c}(2) \\
\text { All banks }\end{array}$ & $\begin{array}{c}\text { (3) } \\
\text { All banks }\end{array}$ & $\begin{array}{c}\text { (4) } \\
\text { All banks }\end{array}$ \\
\hline \multirow{3}{*}{ 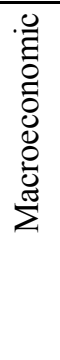 } & Real GDP growth & $\begin{array}{c}0.546^{* * * *} \\
(0.191)\end{array}$ & $\begin{array}{c}0.821^{* * *} \\
(0.199)\end{array}$ & $\begin{array}{c}0.532 * * * \\
(0.187)\end{array}$ & $\begin{array}{c}0.820^{* * *} \\
(0.198)\end{array}$ \\
\hline & Currency depreciation & $\begin{array}{c}0.253 \\
(0.184)\end{array}$ & $\begin{array}{l}0.280 * \\
(0.168)\end{array}$ & $\begin{array}{c}0.260 \\
(0.184)\end{array}$ & $\begin{array}{c}0.295^{*} \\
(0.167)\end{array}$ \\
\hline & Foreign & & & $\begin{array}{c}25.15^{* * *} \\
(4.871)\end{array}$ & $\begin{array}{c}17.56^{* * *} \\
(5.277)\end{array}$ \\
\hline \multirow{11}{*}{ 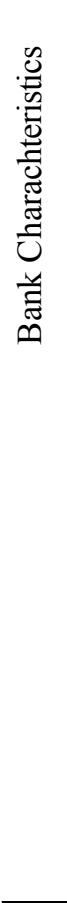 } & NPL/total loans & $\begin{array}{c}-0.284 * * \\
(0.111)\end{array}$ & & $\begin{array}{c}-0.248^{* *} \\
(0.110)\end{array}$ & \\
\hline & ROAA & & $\begin{array}{c}1.308 * * * \\
(0.364)\end{array}$ & & $\begin{array}{c}1.265 * * * \\
(0.362)\end{array}$ \\
\hline & Regulatory capital ratio & $\begin{array}{l}0.358^{*} \\
(0.199)\end{array}$ & $\begin{array}{c}0.294 \\
(0.185)\end{array}$ & $\begin{array}{l}0.367^{*} \\
(0.197)\end{array}$ & $\begin{array}{c}0.304 \\
(0.184)\end{array}$ \\
\hline & Deposit funding ratio & $\begin{array}{c}0.140^{* *} \\
(0.071)\end{array}$ & $\begin{array}{c}0.224 * * * \\
(0.068)\end{array}$ & $\begin{array}{c}0.155^{* *} \\
(0.070)\end{array}$ & $\begin{array}{c}0.234 * * * \\
(0.068)\end{array}$ \\
\hline & Liquidity & $\begin{array}{c}0.050 \\
(0.091)\end{array}$ & $\begin{array}{c}0.097 \\
(0.091)\end{array}$ & $\begin{array}{c}0.068 \\
(0.092)\end{array}$ & $\begin{array}{c}0.115 \\
-0.092\end{array}$ \\
\hline & Constant & $\begin{array}{c}10.20 \\
(6.612)\end{array}$ & $\begin{array}{l}-1.160 \\
(6.433)\end{array}$ & $\begin{array}{l}-6.122 \\
(7.392)\end{array}$ & $\begin{array}{l}-12.59^{*} \\
(7.454)\end{array}$ \\
\hline & Observations & 997 & 1,256 & 997 & 1,256 \\
\hline & R-squared & 0.409 & 0.377 & 0.428 & 0.386 \\
\hline & Number of bankid & 181 & 205 & 181 & 205 \\
\hline & Bank FE & YES & YES & YES & YES \\
\hline & Time FE & YES & YES & YES & YES \\
\hline
\end{tabular}

All bank characteristics with the exception of ownership dummy are lagged one period.

Robust standard errors are in parentheses.

$* * * \mathrm{p}<0.01,{ }^{* *} \mathrm{p}<0.05,{ }^{*} \mathrm{p}<0.1$

Source: Own calculations

\section{Mixed evidence on the impact of liquidity.}

As regards bank liquidity, our results in Table 1 suggest a positive, however, not statistically significant effect on credit growth when looking at both domestic and foreign banks. The findings in the literature have been quite mixed regarding both the direction of the impact of liquidity on credit growth and its significance. 
Figure 6 shows the standardized coefficients of the regressions and allows for the illustration of the relative impact of the explanatory variables on credit growth. Overall, our findings suggest that both macro and bank-level characteristics play a role in driving bank-level credit growth. In terms of relative economic importance, a one standard deviation change of customer deposits ratio to total funding results in a close to 0.2 standard deviation increase in real credit growth. A one standard deviation increase in bank capitalization or profitability is associated with an increase in credit growth of around 0.1 standard deviation. In contrast, NPLs have a significantly constraining impact on real credit growth.

Figure 6: Drivers of credit growth: Table 1, regressions (1) and (2)

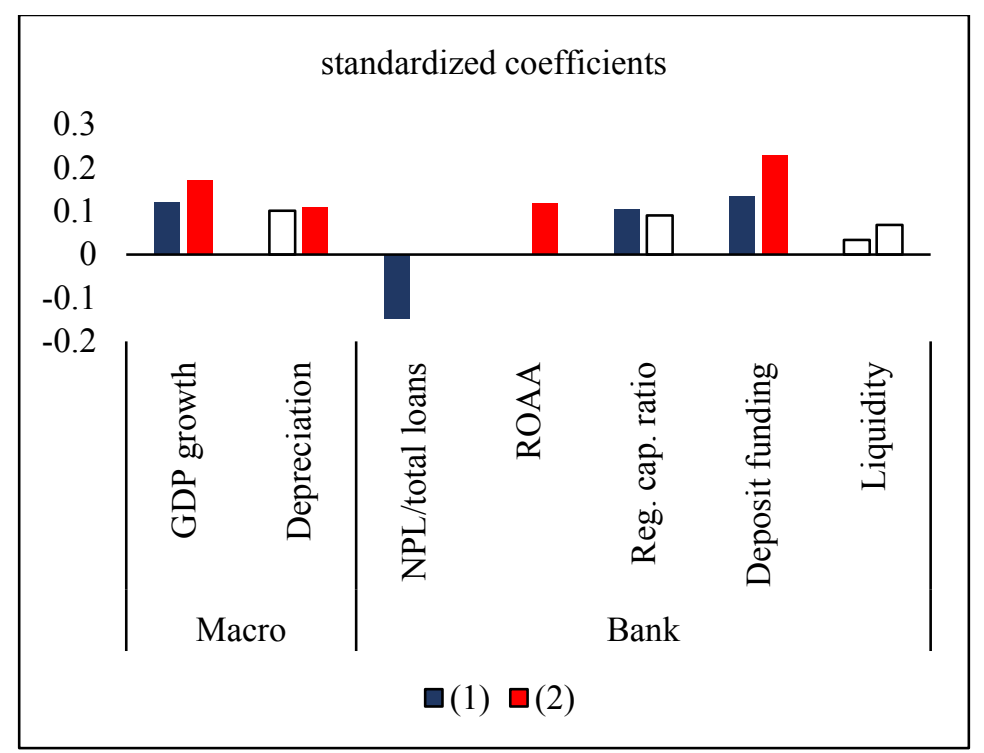

Note: The bars represent the standardized coefficients of our baseline regressions (1) and (2) in Table 1. Nonshaded bars correspond to coefficients that are not statistically significant at the 10 percent significance level.

Source: Own calculations

\section{Heterogeneity across domestic and foreign banks.}

Dummy variables for foreign banks that enter the regressions in columns (3) and (4) of Table 1 are strongly statistically significant, suggesting that there are differences in driving factors (and the importance thereof) of credit for foreign and domestic banks. To understand and disentangle these differences better, we split our sample into domestic and foreign banks and run the baseline specifications for these two subsamples (see Table 2). Columns (1) and (2) in Table 2 contain the same regression specifications as column (1) in Table 1, however, we divide the sample into domestic and foreign banks. Columns (3) and (4) do the same for the specification in column (2) of Table 1. Columns (5) and (6) include both foreign and domestic banks along with the Foreign dummy and some interaction terms.

Our results in Table 2 confirm that there are differences in the driving forces of foreign and domestic banks' lending. GDP remains significant both for domestic and foreign banks. As regards the depreciation rate, the positive association with credit growth holds for both domestic and foreign banks, although it mostly remains not statistically significant and seems more important for foreign banks, likely indicating a larger exposure to subsidiaries of 
foreign corporations. Our results suggest that domestic banks are less sensitive to the state of their balance sheets, as indicated by not statistically significant coefficients on nonperforming loans (columns (1) and (5)). This could indicate that their lending strategy is constrained relative to foreign banks. At the same time, liquidity appears to be an important driver of credit growth for domestic banks (columns (1) and (3)), while it does not have a

Table 2: Drivers of credit growth: domestic vs. foreign

\begin{tabular}{|c|c|c|c|c|c|c|c|}
\hline & & $\begin{array}{c}(1) \\
\text { Domestic } \\
\text { banks }\end{array}$ & $\begin{array}{c}(2) \\
\text { Foreign } \\
\text { banks }\end{array}$ & $\begin{array}{c}(3) \\
\text { Domestic } \\
\text { banks }\end{array}$ & $\begin{array}{c}(4) \\
\text { Foreign } \\
\text { banks } \\
\end{array}$ & All banks & All banks \\
\hline \multirow{4}{*}{ 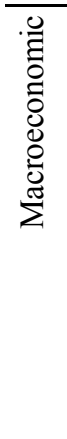 } & Real GDP growth & $\begin{array}{l}0.597^{*} \\
(0.346)\end{array}$ & $\begin{array}{c}0.570^{* *} \\
(0.226)\end{array}$ & $\begin{array}{c}1.144 * * * \\
(0.347)\end{array}$ & $\begin{array}{c}0.650^{* * *} \\
(0.234)\end{array}$ & $\begin{array}{c}0.543 * * * \\
(0.187)\end{array}$ & $\begin{array}{c}0.834 * * * \\
(0.199)\end{array}$ \\
\hline & Currency depreciation & $\begin{array}{c}0.136 \\
(0.303)\end{array}$ & $\begin{array}{c}0.215 \\
(0.215)\end{array}$ & $\begin{array}{l}0.0304 \\
(0.306)\end{array}$ & $\begin{array}{c}0.413 * * \\
(0.198)\end{array}$ & $\begin{array}{c}0.236 \\
(0.185)\end{array}$ & $\begin{array}{l}0.283^{*} \\
(0.168)\end{array}$ \\
\hline & Foreign & & & & & $\begin{array}{c}26.15^{* * *} \\
(4.605)\end{array}$ & $\begin{array}{c}15.77 * * * \\
(5.345)\end{array}$ \\
\hline & NPL/total loans & $\begin{array}{l}-0.073 \\
(0.162)\end{array}$ & $\begin{array}{c}-0.471 * * * \\
(0.146)\end{array}$ & & & $\begin{array}{l}-0.099 \\
(0.119)\end{array}$ & \\
\hline \multirow{12}{*}{ 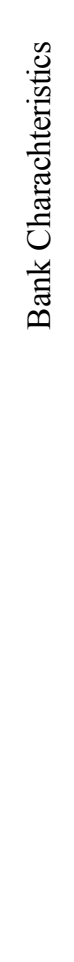 } & ROAA & & & $\begin{array}{l}1.093^{*} \\
(0.579)\end{array}$ & $\begin{array}{c}1.774 * * * \\
(0.406)\end{array}$ & & $\begin{array}{c}0.484 \\
(0.554)\end{array}$ \\
\hline & Regulatory capital ratio & $\begin{array}{l}0.511^{*} \\
(0.268)\end{array}$ & $\begin{array}{c}0.418 \\
(0.301)\end{array}$ & $\begin{array}{c}0.267 \\
(0.235)\end{array}$ & $\begin{array}{c}0.538^{* *} \\
(0.269)\end{array}$ & $\begin{array}{c}0.419^{* *} \\
(0.209)\end{array}$ & $\begin{array}{l}0.331^{*} \\
(0.183)\end{array}$ \\
\hline & Deposit funding ratio & $\begin{array}{c}0.153 \\
(0.117)\end{array}$ & $\begin{array}{c}0.159^{* *} \\
(0.078)\end{array}$ & $\begin{array}{c}0.272^{* *} \\
(0.120)\end{array}$ & $\begin{array}{c}0.162^{* *} \\
(0.081)\end{array}$ & $\begin{array}{c}0.149 * * \\
(0.067)\end{array}$ & $\begin{array}{c}0.220^{* * *} \\
(0.068)\end{array}$ \\
\hline & Liquidity & $\begin{array}{c}0.321^{* *} \\
(0.144)\end{array}$ & $\begin{array}{l}-0.097 \\
(0.103)\end{array}$ & $\begin{array}{c}0.319^{* *} \\
(0.151)\end{array}$ & $\begin{array}{l}-0.042 \\
(0.096)\end{array}$ & $\begin{array}{c}0.078 \\
(0.091)\end{array}$ & $\begin{array}{c}0.112 \\
(0.089)\end{array}$ \\
\hline & Foreign x NPL & & & & & $\begin{array}{c}-0.355^{* *} \\
(0.160)\end{array}$ & \\
\hline & Foreign x ROAA & & & & & & $\begin{array}{l}1.705^{* *} \\
(0.663)\end{array}$ \\
\hline & Constant & $\begin{array}{l}-5.242 \\
(11.91)\end{array}$ & $\begin{array}{c}16.59^{* *} \\
(7.281)\end{array}$ & $\begin{array}{l}-13.49 \\
(12.60)\end{array}$ & $\begin{array}{c}5.516 \\
(6.938)\end{array}$ & $\begin{array}{l}-7.127 \\
(7.469)\end{array}$ & $\begin{array}{l}-11.08 \\
(7.493)\end{array}$ \\
\hline & Observations & 362 & 635 & 487 & 769 & 997 & 1,256 \\
\hline & R-squared & 0.347 & 0.518 & 0.331 & 0.464 & 0.434 & 0.390 \\
\hline & Number of bankid & 71 & 117 & 87 & 127 & 181 & 205 \\
\hline & Bank FE & YES & YES & YES & YES & YES & YES \\
\hline & Time FE & YES & YES & YES & YES & YES & YES \\
\hline
\end{tabular}

All bank characteristics with the exception of ownership dummy are lagged one period.

Robust standard errors are in parentheses.

$* * * \mathrm{p}<0.01, * * \mathrm{p}<0.05, * \mathrm{p}<0.1$

Source: Own calculations 
significant effect on foreign bank credit growth. It is likely that for foreign owned banks their parents' liquidity is more important than their own position. As our sample is dominated by foreign banks, this could also explain liquidity not being significant when looking at the full sample in Table 1 or the last two columns in Table 2. Profitability appears to be a positive factor for credit growth, especially in the case of foreign banks. The deposit funding ratio is positively associated with credit growth both in domestic and foreign banks. As regards the impact of capitalization levels on credit growth, our results tend to support a positive impact of total capital ratios on credit growth.

Figure 7: Drivers of credit growth: Table 2, regressions (1) and (2)

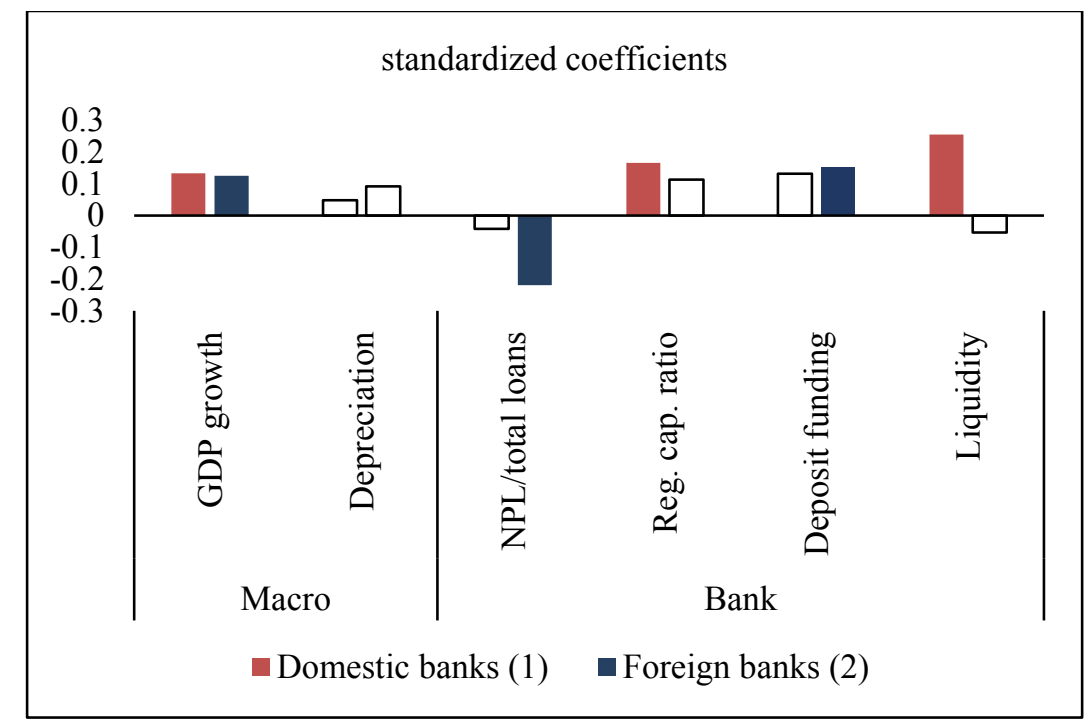

Note: The bars represent the standardized coefficients of regressions (1) and (2) in Table 2. Non-shaded bars correspond to coefficients that are not statistically significant at the 10 percent significance level.

Source: Own calculations

Figure 7 depicts the relative importance of control variables in terms of standardized coefficients from columns (1) and (2) in Table 2. Our regression results suggest differences in the importance of drivers between domestic and foreign banks both in terms of impact size and significance. The plot shows that one standard deviation increase in liquidity in domestic banks is associated with a 0.25 standard deviation increase in real credit growth. The impact on foreign bank credit is both negligible and statistically not significant. In contrast, for foreign banks characteristics such as funding structure, capitalization and especially asset quality appear to be the most important drivers of real credit growth. While not reported here, ROAA takes NPLs' role as the most important driver in the regression in column (3) and (4) in Table 2, while the regulatory capital ratio also becomes an important driver.

Overall, these results suggest that for foreign banks safe (NPLs, capital, deposit funding) and profitable subsidiaries are attractive places to put resources. In contrast, for domestic banks the large importance of (domestic) liquidity points to a potential lack of outside options and less importance of the health and safety of the banks' business. 


\section{B. Empirical evidence on drivers of differential credit growth}

Having illustrated the drivers of and differences in the lending behavior between domestic and foreign banks, in this subsection we look at the foreign bank subsidiaries as an integral part of their parent banks. We then compare the drivers of foreign bank credit growth with those of differential credit growth between subsidiaries in CESEE countries and their parent banks. In order to explore how foreign banks differentiate expansion of their credit portfolios across their host countries relative to their home markets, we take the difference in real credit growth between host and home countries as our dependent variable. To our knowledge, this is the first paper to take this avenue in an attempt to shed some light on why some foreign bank subsidiaries might fare better or worse in terms of credit expansion relative to their home country.

Our generic model specification and control variables are similar to the ones used in the previous section, apart from our dependent variable being differential credit growth or credit growth in foreign bank subsidiaries only. We also include parent bank characteristics to account for the situation of the parent.

$$
\begin{aligned}
& \text { Differential }_{i j t}=\alpha+\beta_{1} \text { Macro }_{j t}+\beta_{2} \text { PMacro }_{i t}+\beta_{3} \text { Bank }_{i j t-1}+\beta_{4} \text { PBank }_{i t}+ \\
& \qquad \beta_{5} \text { Inter }_{i j t}+\mathrm{y}_{t}+\eta_{i}+\varepsilon_{i j t}
\end{aligned}
$$

To facilitate the interpretation of the results, we present the regression analysis in comparison with the drivers of credit growth for foreign subsidiaries (similar to Table 2). As columns (1) and (2) in Table 3 suggest, when controlling for parent bank macroeconomic and bank-level characteristics, the impact of host country macro and bank-level variables remains significant. At the same time, introducing parent bank and macro variables improves the model fit, highlighting the influence (foreign) parent banks have on the credit conditions in CESEE. Columns (3) and (4) have identical specifications to the foreign bank credit growth regressions in the first two columns of the table, however, the dependent variable here is the differential credit growth. In columns (5) - (7) we introduce different parent bank indicators. The interpretation of the regression results on differential credit growth is not straightforward as the magnitude of the coefficients shows the impact on the difference between subsidiary and parent bank credit growth, and does not allow a direct conclusion how much each of the credit numbers are impacted. Our regression results, nevertheless, highlight the importance of different indicators in driving credit dynamics in CESEE.

\section{Economic growth story of home and host countries matters for foreign bank credit expansion but less so for differential credit growth.}

Real GDP growth in the host country does not appear to be a significant factor affecting the parent banks' decision on how to differentiate its credit expansion pace between the home country and a foreign subsidiary (columns (3) - (7) in Table 3). However, it is a significant 
driver of foreign bank credit growth (columns (1) - (2) in Table 3). In contrast, parents' GDP growth positively affects real credit growth in their foreign subsidiaries (columns (1) - (2) in Table 3) as well as differential credit growth in the majority of model specifications. We should also note the strong positive correlation between economic growth in home and host countries. This is not surprising, given the tight integration of CESEE countries in the supply chains of the Western European countries, where the parents of foreign banks predominantly come from. This correlation, however, does not impact the rest of the results, as implied by the regressions where we introduce the two variables one by one (for brevity considerations these are not reported).

\section{Overall, parent bank characteristics play a significant role in driving both credit growth and differential credit growth.}

- Our results suggest that high profitability of parent banks positively impacts lending by their foreign subsidiaries, while, constraining differential credit growth (column (1) vs. columns (3) and (4) in Table 3). Higher profitability of the parent bank in its home market is associated with higher credit growth in subsidiaries, acting like a "push" factor. However, parent banks which are profitable in their domestic markets seem to expand their credit less in subsidiaries, as implied by the negative coefficient on parent ROAA in differential credit regressions (columns (3) - (4) in Table 3). Thus, if the profitability in the parent bank's home market is high enough, it might prefer to allocate only part of the resulting resources to its subsidiary. Nevertheless, interaction terms with crisis dummies in column (7) of Table 3 suggest that, at the height of the crisis a profitable parent was likely to have a positive impact on the differential credit growth. Profitability of the subsidiary remains an often positive "pull" factor for differential credit growth, although not statistically significant.

- Parent liquidity appears to have a significant negative impact on credit growth of subsidiaries as well as differential credit growth as implied by the regression results in Table 3. This could suggest that more liquid parents are also likely to be more risk averse and thus have a more conservative strategy of growing their credit portfolios in the foreign subsidiaries. ${ }^{9}$ This seems to be the case especially if the parent banks have high levels of NPLs based on the interaction term in column (6). Nevertheless, we find some evidence that this was reversed temporarily during the GFC years and more liquid banks acted as a source of strength for their subsidiaries (column (7) in Table 3).

- Parent capitalization negatively impacts differential credit growth (column (5) of table 3). This is particularly the case where the parent is weighed down by higher levels of NPLs (column (6) of Table 3 ). This could point toward better capitalized banks being more risk averse and thus having less aggressive credit expansion strategies for their foreign subsidiaries. It could also be the result of higher credit growth in the home market. In the context of significantly increased regulatory capital requirements in home markets postcrisis, arguably it could also be a sign of parent banks retaining their resources to build up their own capital buffers rather than taking up growth opportunities in their subsidiaries. This finding provides support to the argument that stricter home country regulation

\footnotetext{
${ }^{9}$ This is in line with de Haas and van Lelyveld 2010.
} 
Table 3: Drivers of foreign bank credit and differential credit growth

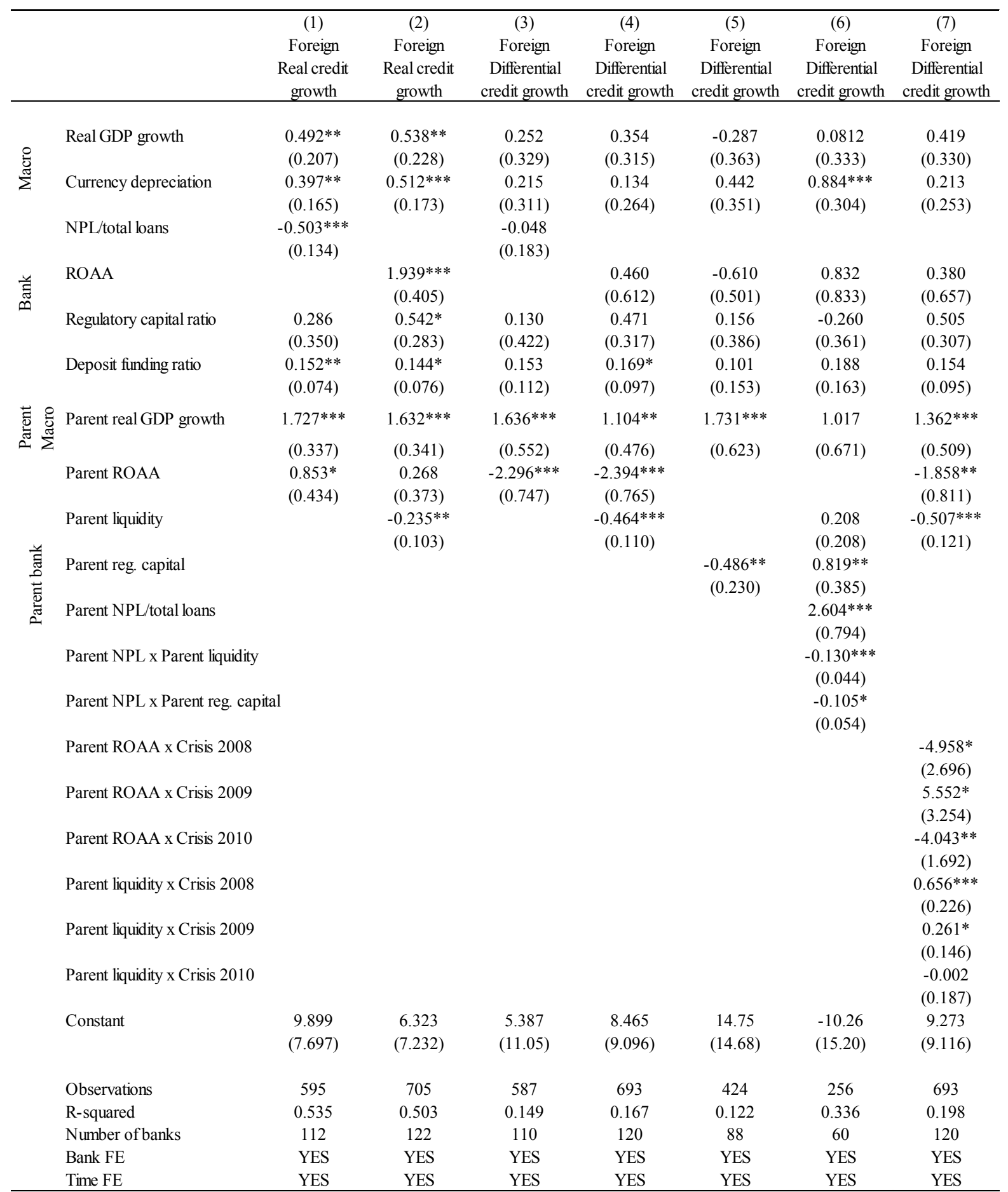

All bank characteristics with the exception of ownership dummy are lagged one period.

Robust standard errors are in parentheses.

$* * * \mathrm{p}<0.01,{ }^{*} * \mathrm{p}<0.05, * \mathrm{p}<0.1$

Source: Own calculations

CInternational Monetary Fund. Not for Redistribution 
results in foreign banks exporting a more conservative model abroad rather than searching for yield (see Ongena et al. 2013).

- Worsening asset quality in the parent banks' home markets leads to smaller differential credit growth (accounting for the impact of the interaction terms), likely implying that downward credit adjustment in the subsidiaries outpaces that in the home markets of foreign banks (column (6) in Table 3). The interplay of parent liquidity and capitalization with parent NPLs also suggests that parent banks with poorer asset quality tend to have a more negative impact on differential credit growth via the liquidity and capital channels. Controlling for the parent characteristics of foreign banks, does not affect the significance or magnitude of the negative impact of subsidiary NPL levels on credit growth compared to the results shown in the previous section (column (1) of Table 3 ). This implies that a parent bank is less likely to expand its portfolio in subsidiaries that have a high burden of bad loans. This points to caution in the face of risks to parent bank resources it can also employ elsewhere and strengthens the conclusion from section A.

Parent liquidity seems to be by far the strongest driver of differential credit growth when looking at standardized regression coefficients (see Figure 8). One standard deviation increase in parent liquidity translates into an over 0.3 standard deviation contraction in differential credit growth, according to regression (4) from Table 3. Given that this is consistent with the regressions on credit growth, this could imply that a high level of parent liquidity is a sign of a cautious strategy by limiting the exposure of parent to subsidiary

Figure 8: Drivers of differential credit growth vs. foreign bank credit, Table 3, regressions (2) and (4)

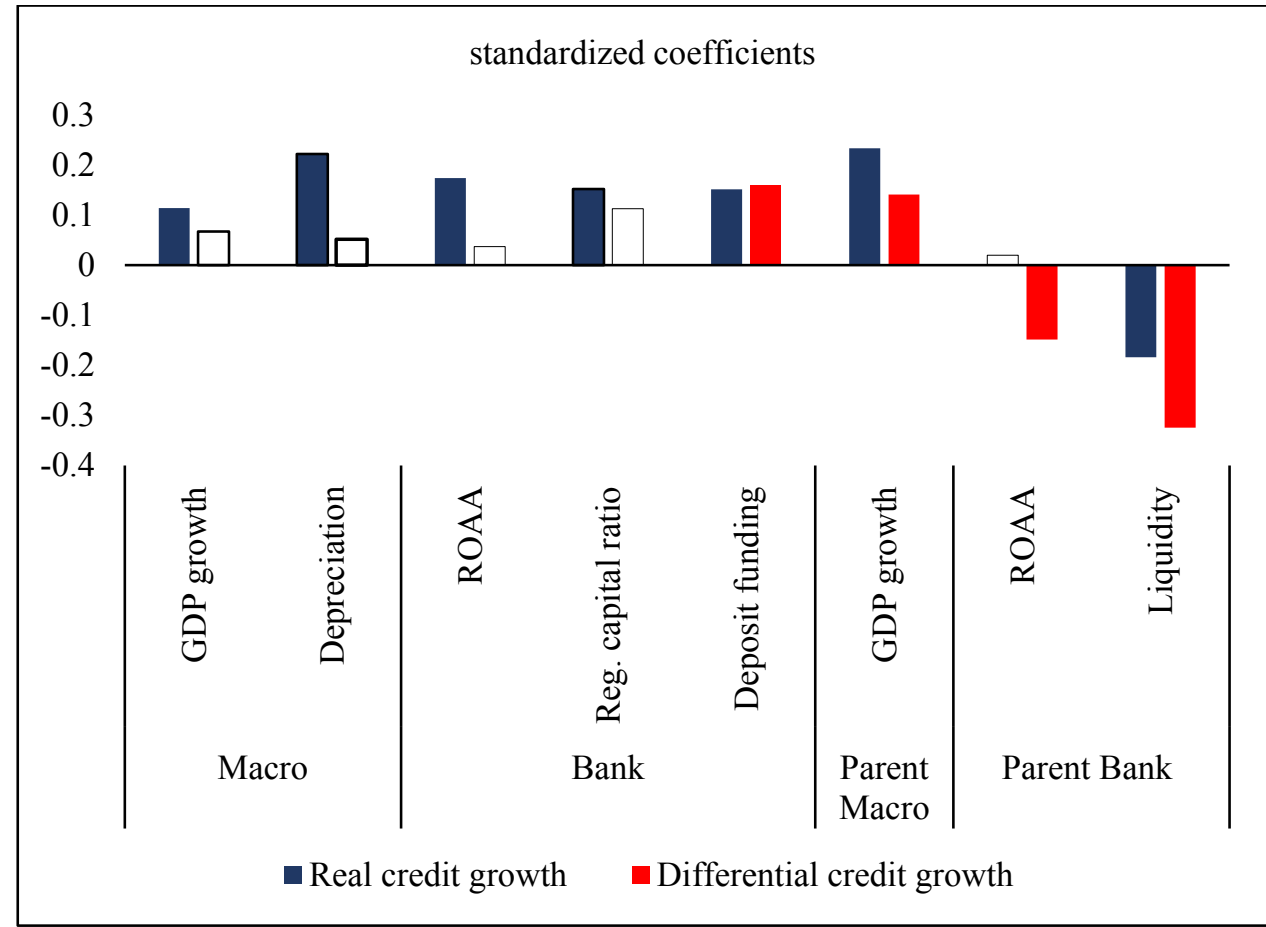

Note: The bars represent the standardized coefficients of our baseline regressions (2) and (4) in Table 3. Nonshaded bars correspond to coefficients that are not statistically significant at the 10 percent significance level.

Source: Own calculations 
activity. Moreover, the consistent importance of liquidity across regressions suggests that parents' liquidity issues can be transmitted into their subsidiaries. Subsidiary-level liquidity is omitted in the reported regressions as it appeared to be neither economically nor statistically significant both for foreign bank credit growth and differential credit growth.

Overall, the comparison of the drivers of credit and differential credit growth suggests that subsidiary-level characteristics play an important role for credit growth but less so for differential credit. While foreign banks allocated their liquidity/resources to subsidiaries primarily based on the subsidiaries health, safety and profitability, this decision is subject to the parents' own health and profitability. Thus, regulators in CESEE face a complex task assessing their banking systems' health and vulnerabilities.

\section{Robustness checks}

In this sub-section, we summarize some of the alternative model specifications and estimation methods used in order to check the robustness of our baseline model specifications.

Results are robust to using alternative macro and bank-level variables. Our baseline regressions are robust to various model specifications, some of which were already mentioned in the previous sections. We tested a number of other variables, which showed a less robust and/or significant performance and did not qualitatively affect the reported results. On the macroeconomic side, these include inflation, index of governance quality (proxied by the World Banks's governance indicators (WGI)) as well as overall level of financial deepening (proxied by credit to the private sector relative to GDP). Given that in most of the CESEE countries euro-denominated lending is prevalent, we also tried substituting the exchange rate of local currency vs. the US dollar, with the exchange rate vs. the euro. As columns (1) - (2) of Table A3 show, this does not impact the remaining control variables. As another alternative, we introduce the policy rate into our regressions, while the sign suggests that an increase in interest rates in the host economies is negatively associated with credit growth, the results often appeared not statistically significant (column (3) of Table A3).

Weak evidence of bank size impact on credit growth or differential credit growth. We test the hypothesis of whether the size of the banks has any statistically significant impact on (differential) credit growth. We capture bank size in two ways: as a share of the bank in the banking sector measured by assets as well as relative to the size of the parent. One might consider that smaller banks, relative to the banking sector size, are likely to grow at a faster pace compared to their larger and more established competitors in the market. In contrast, the larger the subsidiary relative to its parent bank the more committed the parent bank might be to growing the subsidiary. We do not find any statistically significant results for the impact of size on credit growth. As expected, however, the impact of the subsidiary size on credit growth is consistently negative (column (4) of Table A3) and larger subsidiaries of parent banks are associated with faster credit growth (column (5) of Table A3).

Eliminating subsidiaries of Italian or Greek parent banks does not qualitatively impact the results. As an alternative robustness check we split our sample by the home countries of foreign banks. Columns (6) and (7) in Table A3 show regressions where the foreign subsidiaries whose parent banks are Italian or Greek banks are dropped. These make up 
almost a quarter of our foreign bank observations and have the most volatile credit growth among parent banks. The regression results imply that despite dropping these most volatile observations, our baseline results largely hold.

Results are robust to using system Generalized Method of Moments (GMM) as an alternative estimation method. To address the issues of autocorrelation in credit growth and potential endogeneity of bank-specific variables, we also estimate some of the model specifications using system GMM. This expanded estimator includes lagged levels in addition to first differences in Arellano-Bond difference GMM. The reported results of Hansen test for overidentifying restrictions and the Arellano-Bond test for serial correlation support the validity of the instruments. ${ }^{10}$ As in the baseline, all the specifications include time fixed effects to control for common shocks. As suggested by Table A4, our results are largely robust to GMM estimation method.

\section{CONCLUding REMARKS}

Our findings provide some new post-crisis evidence on the drivers of credit growth dynamics in CESEE over the last decade that included the pre-GFC boom, the GFC and the subsequent recovery as well as the more recent euro area crisis. Similar to previous studies, our findings suggest significant differences between the lending behavior of foreign and domestic banks that cannot solely be explained by macroeconomic or bank-level characteristics.

- For subsidiaries of foreign banks, we identify the important role that subsidiary and parent bank characteristics play for credit growth. Specifically, bank-level characteristics such as funding structure, asset quality, capitalization levels and profitability appear to be among the most important credit drivers.

- Regarding "differential" credit growth (namely differences in the pace of credit growth between subsidiaries and parents; home jurisdictions), parent bank characteristics such as liquidity, profitability, capitalization and asset quality appear to play a vital role.

From a policy perspective, these findings provide further empirical justification for a continued regulatory push and cooperation for a more efficient NPL resolution mechanisms. The analysis also raises questions related to possible cross-border spillovers of regulatory actions from banks" "home" to "host" jurisdictions. Given the wide-ranging overhaul of the regulatory environment following the crisis, as well as legacy issues such as elevated NPLs in many EU countries, policymakers in CESEE should be aware not only of foreign banks' domestic operations but also need to take a broader view including the international regulatory environment and potential (up-coming) regulatory changes in the jurisdictions where their foreign banks' parents reside.

\footnotetext{
${ }^{10}$ We restrict the number of lags in constructing GMM instruments to fourth lag, to avoid overfitting for the first differenced equations. For the levels equations we use the one period lagged first differences as instruments.
} 


\section{REFERENCES}

Arakelyan, M. \& Mühlberger, M., 2015. CEE corporate bonds: Untapped potential but challenges remain. Deutsche Bank Research, Research Briefing.

Arena, M., Reinhart, C. \& Vázquez, F., 2007. The Lending Channel in Emerging Economies: Are Foreign Banks Different? IMF Working Paper, 07/48.

Balgova, M., Nies, M. \& Plekhanov, A., 2016. The economic impact of reducing nonperforming loans. EBRD Working Paper, (193).

Bank of International Settlements (BIS), 2012. Report on intra-group support measures,

Barba Navaretti, G. et al., 2010. Multinational banking in Europe - financial stability and regulatory implications: Lessons from the financial crisis. CEPR Discussion Papers 7823.

Barisitz, S., 2011. Nonperforming Loans in CESEE - What Do They Comprise ? Focus on European Economic Integration Q4/11, Oesterreichische Nationalbank (Austrian Central Bank), issue 4, pp.46-68.

Bayraktar, N. \& Wang, Y., 2004. Foreign Bank Entry, Performance of Domestic Banks and the Sequence of Financial Liberalization. Policy Research Working Paper Series 3416, The World Bank.

Bonin, J.P. \& Louie, D., 2016. Did foreign banks stay committed to emerging Europe during recent financial crises? Journal of Comparative Economics, pp.1-16.

Brown, M. et al., 2012. Who Needs Credit and Who Gets Credit in Eastern Europe? Working Paper Series 1421, European Central Bank.

Cerutti, E., Dell'Ariccia, G. \& Martínez Pería, M.S., 2007. How banks go abroad: Branches or subsidiaries? Journal of Banking and Finance, 31(6), pp.1669-1692.

Cetorelli, N. \& Goldberg, L.S., 2010. Global Banks and International Shock Transmission: Evidence from the Crisis. IMF Economic Review, 59(1), pp.41-76.

Cetorelli, N. \& Goldberg, L.S., 2012. Liquidity management of U.S. global banks: Internal capital markets in the great recession. Journal of International Economics, 88(2), pp.299-311.

Chen, G. \& Wu, Y., 2014. Bank Ownership and Credit Growth in Emerging Markets During and After the 2008 - 09 Financial Crisis - A Cross-Regional Comparison. IMF Working Paper, 14/171.

Choi, M.J., Gutierrez, E. \& Martínez Pería, M.S., 2013. Dissecting foreign bank lending behavior during the 2008-2009 crisis. Policy Research Working Paper Series 6674, The World Bank.

Claessens, S., Demirguc-Kunt, A. \& Huizinga, H., 2001. How does foreign entry affect domestic banking markets? Journal of Banking \& Finance, 25(5), pp.891-911.

Claessens, S. \& van Horen, N., 2014. Foreign banks: Trends and Impact. Journal of Money, Credit and Banking, 41(1), pp.295-326.

Claessens, S. \& van Horen, N., 2013. Impact of foreign banks. Journal of Financial 
Perspectives, EY Global FS Institute, 1(1), pp.29-42.

Claessens, S. \& van Horen, N., 2008. Location Decisions of Foreign Banks and Institutional Competitive Advantage. DNB Working Papers 172.

Clarke, G. et al., 2001. Foreign Bank Entry: Experience, Implications for Developing Countries, and Agenda for Further Research. The World Bank, Policy Research Working Paper, 2698.

Cull, R. \& Martínez Pería, M.S., 2013. Bank ownership and lending patterns during the 2008-2009 financial crisis: Evidence from latin America and Eastern Europe. Journal of Banking and Finance, 37(12), pp.4861-4878.

Cull, R., Martínez Pería, M.S. \& Verrier, J., 2017. Bank Ownership : Trends and Implications. IMF Working Paper, 17/60.

Cull, R.J. \& Martínez Pería, M.S., 2010. Foreign Bank Participation in Developing Countries: What Do We Know about the Drivers and Consequences of This Phenomenon? Policy Research Working Paper Series 5398, The World Bank.

Detragiache, E., Tressel, T. \& Gupta, P., 2008. Foreign Banks in Poor Countries: Theory and Evidence. Journal of Finance, 63(5), pp.2123-2161.

de Haas, R. et al., 2015. Taming the herd? Foreign banks, the Vienna Initiative and crisis transmission. Journal of Financial Intermediation, 24(3), pp.325-355.

de Haas, R., 2014. The Dark and the Bright Side of Global Banking: A (Somewhat) Cautionary Tale from Emerging Europe. Comparative Economic Studies, vol 56(2), pp.271-282.

de Haas, R. \& van Lelyveld, I., 2006. Foreign banks and credit stability in Central and Eastern Europe. A panel data analysis. Journal of Financial Intermediation, 30(7), pp.1927-1952.

de Haas, R. \& van Lelyveld, I., 2010. Internal capital markets and lending by multinational bank subsidiaries. Journal of Financial Intermediation, Elsevier, 19(1), pp.1-25.

de Haas, R. \& van Lelyveld, I., 2014. Multinational banks and the global financial crisis: Weathering the perfect storm? Journal of Money, Credit and Banking, 46(s1), pp.333364.

European Investment Bank, 2014. CESEE Bank Lending Survey.

Feyen, E. et al., 2014. The impact of funding models and foreign bank ownership on bank credit growth: is Central and Eastern Europe different? Policy Research Working Paper Series 6783, The World Bank.

Focarelli, D. \& Pozzolo, A.F., 2005. Where Do Banks Expand Abroad? An Empirical Analysis. The Journal of Business, 78(6), pp.2435-2464.

Giannetti, M. \& Ongena, S., 2012. "Lending by example": Direct and indirect effects of foreign banks in emerging markets. Journal of International Economics, 86(1), pp.167180.

International Monetary Fund (IMF), 2015. Global Financial Stability Report - International Banking After the Crisis: Increasingly local and safer?, (April), pp.55-91. 
International Monetary Fund (IMF), 2013. Regional Economic Issues - Central, Eastern and Southeastern Europe., (April).

Kapan, T. \& Minoiu, C., 2013. Balance Sheet Strength and Bank Lending During the Global Financial Crisis. IMF Working Paper, 13/102.

Ongena, S., Peydro, J.L. \& van Horen, N., 2015. Shocks Abroad, Pain at Home? Bank-FirmLevel Evidence on the International Transmission of Financial Shocks. DNB Working Papers 385, 63(4), pp.698-750.

Peek, J. \& Rosengren, E.S., 2000. Collateral Damage: Effects of the Japanese Bank Crisis on Real Activity in the United States. American Economic Association, 90(1), pp.30-45.

Stepanyan, V. \& Guo, K., 2011. Determinants of Bank Credit in Emerging Market Economies. IMF Working Paper, 11/51. 


\section{APPENDIX}

Table A 1: Data sources

\begin{tabular}{|c|c|c|c|}
\hline & Variable & Unit & Source \\
\hline \multirow{4}{*}{$\begin{array}{l}\stackrel{\circ}{0} \\
\sum \\
\end{array}$} & Real GDP growth & $\%$ yoy & IMF WEO \\
\hline & Currency depretiation & $\%$ yoy & Haver, IMF IFS \\
\hline & CPI inflation & $\%$ yoy & IMF WEO \\
\hline & Policy rate & $\%$ & Haver \\
\hline \multirow{7}{*}{ 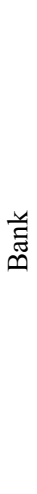 } & Foreign ownership & dummy & Bankscope \\
\hline & Gross loans & local currency & Bankscope, Fitch Connect \\
\hline & Impaired loans (NPLs) / Gross loans & $\%$ & Bankscope, Fitch Connect \\
\hline & ROAA & $\%$ & Bankscope, Fitch Connect \\
\hline & Total regulatory capital ratio & $\%$ & Bankscope, Fitch Connect \\
\hline & Liquidity/Total assets & $\%$ & Bankscope, Fitch Connect \\
\hline & Customer deposits/Total funding & $\%$ & Bankscope, Fitch Connect \\
\hline
\end{tabular}

Table A 2: Descriptive statistics

\begin{tabular}{|c|c|c|c|c|c|c|c|c|c|c|}
\hline & & $\%$ & $\begin{array}{c}\text { Real Credit } \\
\text { growth }\end{array}$ & $\begin{array}{l}\text { Real GDP } \\
\text { growth }\end{array}$ & $\begin{array}{l}\text { Exchange } \\
\text { rate } \\
\text { depreciation }\end{array}$ & NPLs & $\begin{array}{c}\text { Deposit } \\
\text { funding ratio }\end{array}$ & $\begin{array}{c}\text { Profitability } \\
\text { (ROAA) }\end{array}$ & Liquidity & Capitalization \\
\hline \multirow[t]{4}{*}{ All banks } & Pre-crisis & Mean & 24.1 & 5.6 & -6.3 & 4.6 & 72.2 & 1.3 & 28.4 & 16.0 \\
\hline & & Std. dev. & 25.0 & 2.7 & 4.9 & 5.0 & 21.2 & 2.4 & 15.7 & 7.3 \\
\hline & Post-crisis & Mean & 3.0 & 0.4 & 3.7 & 13.7 & 74.4 & 0.0 & 18.9 & 16.0 \\
\hline & & Std. dev. & 17.5 & 3.7 & 7.6 & 10.6 & 20.6 & 3.3 & 14.0 & 4.2 \\
\hline \multirow[t]{4}{*}{ Domestic } & Pre-crisis & Mean & 22.7 & 5.6 & -6.0 & 5.8 & 77.5 & 1.6 & 29.2 & 18.1 \\
\hline & & Std. dev. & 27.0 & 3.0 & 4.5 & 6.5 & 21.1 & 2.9 & 16.1 & 8.8 \\
\hline & Post-crisis & Mean & 4.6 & 0.1 & 3.2 & 15.9 & 80.3 & -0.4 & 22.0 & 15.4 \\
\hline & & Std. dev. & 19.8 & 4.1 & 7.1 & 12.3 & 21.4 & 4.4 & 17.4 & 4.7 \\
\hline \multirow[t]{4}{*}{ Foreign } & Pre-crisis & Mean & 25.0 & 5.6 & -6.6 & 3.9 & 68.5 & 1.1 & 27.9 & 14.7 \\
\hline & & Std. dev. & 23.4 & 2.4 & 5.1 & 3.6 & 20.5 & 1.8 & 15.3 & 5.7 \\
\hline & Post-crisis & Mean & 1.9 & 0.6 & 4.0 & 12.5 & 70.5 & 0.2 & 16.9 & 16.4 \\
\hline & & Std. dev. & 15.8 & 3.3 & 8.0 & 9.3 & 19.1 & 2.3 & 10.9 & 3.9 \\
\hline
\end{tabular}

Sources: Bankscope, Fitch Connect, IMF, Haver 
Table A 3: Alternative model specifications

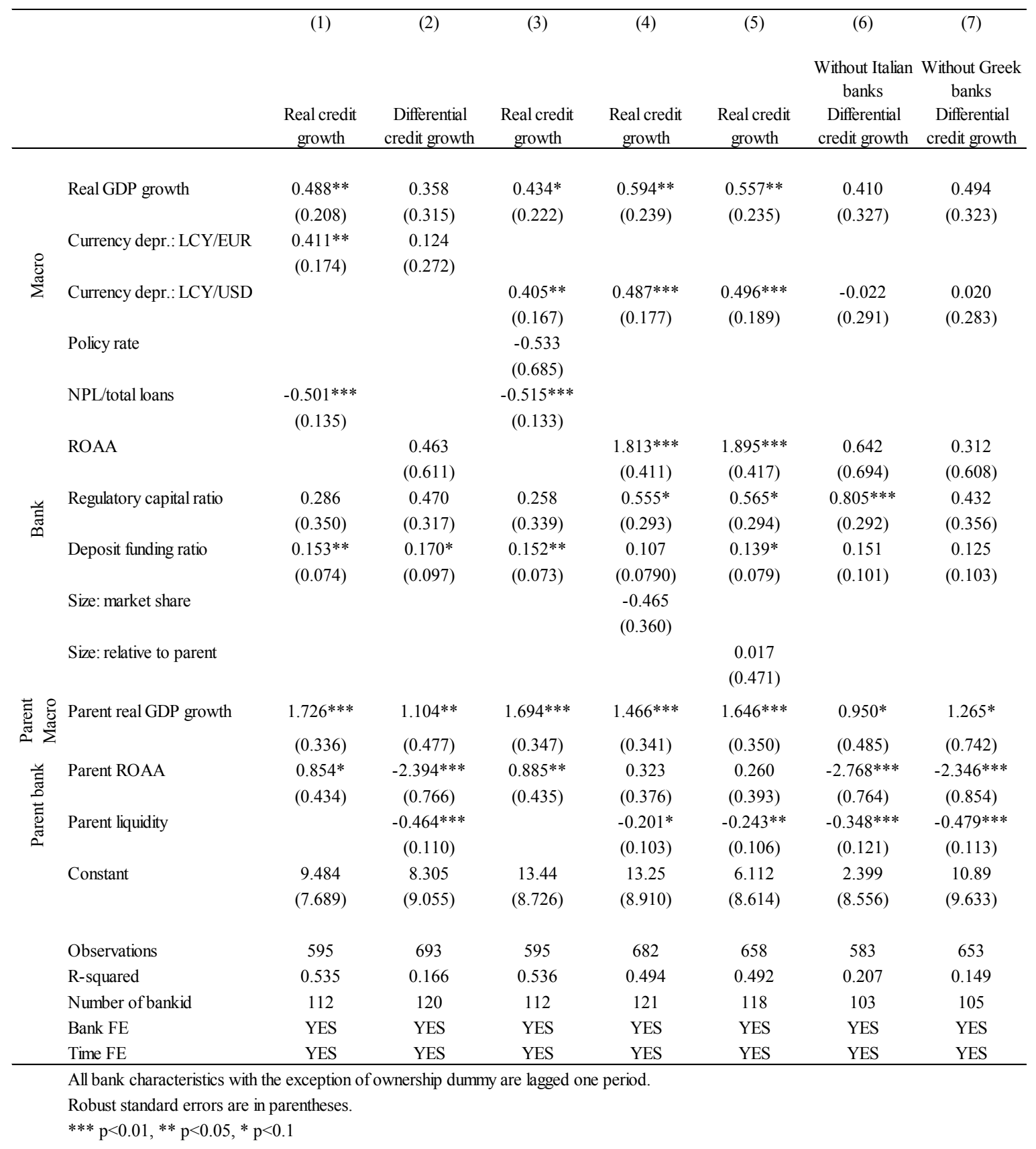

Source: Own calculations 
Table A 4: Alternative estimation method (GMM)

\begin{tabular}{|c|c|c|c|c|c|}
\hline & & (1) & (2) & (3) & (4) \\
\hline & & $\begin{array}{c}\text { Table 1, } \\
\text { Column (1) }\end{array}$ & $\begin{array}{c}\text { Table 1, } \\
\text { Column (2) }\end{array}$ & $\begin{array}{c}\text { Table 3, } \\
\text { Column (1) }\end{array}$ & $\begin{array}{c}\text { Table } 3, \\
\text { Column (2) }\end{array}$ \\
\hline & Lag of credit growth & $\begin{array}{c}0.098 \\
(0.091)\end{array}$ & $\begin{array}{c}0.083 \\
(0.060)\end{array}$ & $\begin{array}{c}0.340 * * * \\
(0.105)\end{array}$ & $\begin{array}{c}0.267 * * * \\
(0.098)\end{array}$ \\
\hline & Real GDP growth & $0.644 * * *$ & $0.952 * * *$ & 0.311 & $0.469^{*}$ \\
\hline : & & $(0.233)$ & $(0.219)$ & $(0.287)$ & $(0.254)$ \\
\hline & Currency depreciation & 0.036 & 0.047 & 0.105 & 0.192 \\
\hline & & $(0.144)$ & $(0.151)$ & $(0.168)$ & $(0.191)$ \\
\hline & NPL/total loans & $-0.395 * * *$ & & $-0.252 *$ & \\
\hline & & $(0.120)$ & & $(0.137)$ & \\
\hline & ROAA & & $0.969 *$ & & 1.107 \\
\hline & & & $(0.573)$ & & $(0.840)$ \\
\hline Еี & Regulatory capital ratio & $0.806 * * *$ & $0.610 * *$ & $1.048 * *$ & $0.776^{*}$ \\
\hline & & $(0.298)$ & $(0.306)$ & $(0.446)$ & $(0.449)$ \\
\hline & Deposit funding ratio & $0.161 *$ & $0.164 *$ & 0.112 & 0.130 \\
\hline & & $(0.086)$ & $(0.088)$ & $(0.103)$ & $(0.080)$ \\
\hline & Liquidity & -0.082 & -0.132 & & \\
\hline & & $(0.133)$ & $(0.124)$ & & \\
\hline 률 & Parent real GDP growth & & & $0.732 * *$ & $1.190 * * *$ \\
\hline$\approx \Sigma$ & & & & $(0.338)$ & $(0.369)$ \\
\hline 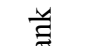 & Parent ROAA & & & 0.458 & 0.431 \\
\hline$\stackrel{5}{2}$ & & & & $(0.454)$ & $(0.389)$ \\
\hline ల్ర్ప & Parent liquidity & & & & $-0.130 * *$ \\
\hline$\tilde{\infty}$ & & & & & $(0.056)$ \\
\hline & Observations & 962 & 1,192 & 576 & 672 \\
\hline & Number of banks & 179 & 204 & 110 & 121 \\
\hline & Time fixed effects & YES & YES & YES & YES \\
\hline & Hansen J & 0.306 & 0.163 & 0.197 & 0.196 \\
\hline & Arellano-Bond test AR1 & 0.00 & 0.00 & 0.00 & 0.00 \\
\hline & Arellano-Bond test AR1 & 0.560 & 0.303 & 0.773 & 0.513 \\
\hline
\end{tabular}

Source: Own calculations 